Universidade de São Paulo

Faculdade de Zootecnia e Engenharia de Alimentos

NATALIA FERNANDA DA CRUZ GREGORIO

Desenvolvimento de Sistema de Sensores para Identificação de Fraude no Leite Bovino

Pirassununga

2019 
NATALIA FERNANDA DA CRUZ GREGORIO

\section{Desenvolvimento de Sistema de Sensores para Identificação de Fraude no Leite Bovino}

\section{Versão Corrigida}

Dissertação de Mestrado apresentada à banca avaliadora para obtenção do título de Mestre pelo Programa de Mestrado Profissional em Gestão e Inovação na Indústria Animal.

Área de Concentração: Gestão e Inovação na Indústria Animal.

Orientador: Prof. Dr. Adriano Rogério Bruno Tech. 
Ficha catalográfica elaborada pelo

Serviço de Biblioteca e Informaçāo, FZEA/USP, com os dados fornecidos pelo(a) autor(a)

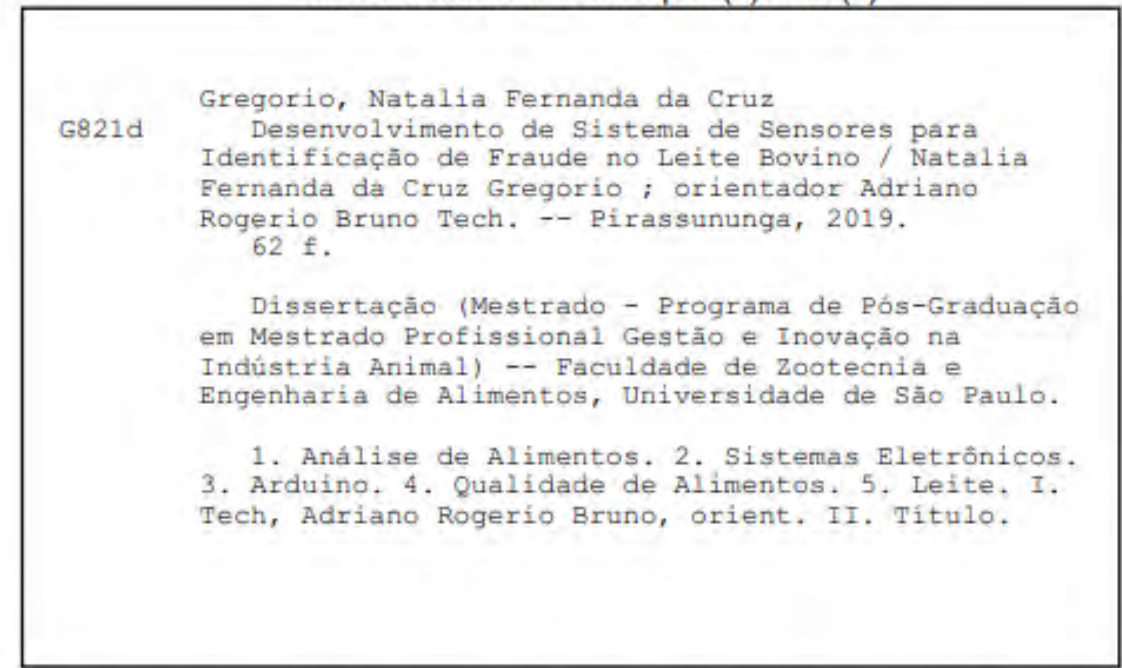

Permitida a copia total ou parcial deste documento, desde que citada a fonte - o autor 


\section{Desenvolvimento de Sistema de Sensores para Identificação de Fraude no Leite Bovino}
Dissertação apresentada à Faculdade de Zootecnia e Engenharia de Alimentos da Universidade de São Paulo, como parte dos requisitos para a obtenção do Título de Mestre em Gestão e Inovação na Industria Animal
Área de Concentração: Gestão e Inovação na Indústria Animal

Data de aprovação:

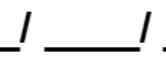

Banca Examinadora:

Prof. Dr.

Instituição

Presidente da Banca Examinadora

Prof.(a) Dr.(a)

Instituição

Prof.(a) Dr.(a)

Instituição 


\section{Agradecimentos}

Aos meus pais, meu orientador, meus amigos, meus familiares e todos que me apoiaram nessa caminhada, longa, complexa e repleta de entraves, deixo aqui minha gratidão. Agradeço por me ouvirem, me ajudarem e me apoiarem, por me darem broncas quando necessário e por me levantar quando caía, por estarem ao meu lado durante essa jornada.

Agradeço também à DVAGRO - Divisão de Produção Agropecuária da prefeitura do campus da Faculdade de Zootecnia e Engenharia de Alimentos (FZEA/USP) pela doação do leite cru, em especial ao chefe da Seção de Bovinos Leiteiros, André Valente de Sá e sua equipe pelo fornecimento de dados e pela disponibilidade e apoio para a realização das coletas de leite.

Aos professores doutores Fabrício Rossi e Tamara Maria Gomes por cederem equipamentos para a realização do projeto, bem como à professora Giovana Tommaso por me permitir utilizar seu laboratório (LBA - Laboratório de Biotecnologia Ambiental) e, por último e não menos importante, às técnicas Ana Cristina Machado Vasconcelos e Tatiana Cardoso Sanches por todo o apoio e auxílio prestado.

Muito obrigada. 


\section{Epígrafe}

Descobrir consiste em olhar para o que todo mundo está vendo e pensar uma coisa diferente.

Roger Von Oech 


\section{Lista de llustrações}

Figura 1. Estrutura da $\alpha$-Lactose.

Figura 2. Principais rotas de contaminação química do leite.

Figura 3. Tipos de Arduino: (a) Arduino Nano; (b) Arduino Uno; (c) Arduino LilyPad;

(d) Arduino Mega. 16

Figura 4. Arduino Uno 22

Figura 5. Sensor de $\mathrm{pH}$ do tipo SEM 0161 22

Figura 6. Sensor Termopar Tipo-K 23

Figura 7. Sensor de Condutividade 23

Figura 8. Protótipo do sistema de identificação de fraude em leite 24

Figura 9. Produção de Soluções para análise. 27

Figura 10. Experimento montado. 30 


\section{Lista de Quadros e Tabelas}

Tabela 1. Composição do Leite. 6

Tabela 2. Composição dos lipídios de duas espécies. 8

Tabela 3. Consequências da exposição humana ao formol em determinadas concentrações. 20

Tabela 4. Especificações técnicas do Sensor de Temperatura Termopar Tipo-K 23

Tabela 5. Metodologia de análise de qualidade do leite utilizada pela APCBRH. 25

Tabela 6. Resultados das Análises de Qualidade do Leite. 26

Quadro 1. Concentrações das soluções Ureia vs. Água. 29

Tabela 7. Médias da condutividade em relação à concentração de hidróxido de sódio intencionalmente adicionado ao leite. 34

Tabela 8. Médias da Condutividade em relação à Concentração de hidróxido de sódio intencionalmente adicionado ao leite azedo. 36

Tabela 9. Médias da Condutividade em relação à Concentração de hidróxido de sódio intencionalmente adicionado ao leite integro. 36

Tabela 10. Médias da Temperatura em relação à Concentração de hidróxido de sódio intencionalmente adicionado ao leite. 38

Tabela 11. Médias da Temperatura em relação à Concentração de hidróxido de sódio intencionalmente adicionado ao leite Azedo. 39

Tabela 12. Médias da temperatura em relação à concentração de peróxido de hidrogênio intencionalmente adicionado ao leite.

Tabela 13. Médias da temperatura em relação à concentração de peróxido de hidrogênio intencionalmente adicionado ao leite azedo.

Tabela 14. Médias da condutividade em relação à concentração de formaldeído intencionalmente adicionado ao leite integro.

Tabela 15. Médias da Temperatura em relação à Concentração de formaldeído intencionalmente adicionado ao leite.

Tabela 16. Médias da temperatura em relação à concentração de formaldeído intencionalmente adicionado ao leite azedo.

Tabela 17. Médias da Temperatura em relação à Concentração de formaldeído intencionalmente adicionado ao leite integro.

Tabela 18. Definição do valor de cada Tratamento frente as concentrações de água e ureia adicionadas ao leite. 50

Quadro 2. Eficiência de cada variável para identificar em cada tipo de leite a adição dos adulterantes estudados. 


\section{Lista de Gráficos}

Gráfico 1. Resposta média da condutividade do leite adicionado ou não de $\mathrm{NaOH}$ em função da concentração.

Gráfico 2. Resposta da condutividade do leite azedo e do leite íntegro adicionado ou não de $\mathrm{NaOH}$ em função da concentração.

Gráfico 3. Médias de Temperatura do leite adicionado ou não de $\mathrm{NaOH}$ em função da concentração.

Gráfico 4. Resposta da Temperatura do leite adicionado ou não de $\mathrm{NaOH}$ em função da concentração.

Gráfico 5. Resposta da Temperatura do leite integro adicionado ou não de $\mathrm{NaOH}$ em função da concentração.

Gráfico 6. Resposta da condutividade do leite adulterado ou não com formol diante da condição (Azedo e Integro).

Gráfico 7. Médias de temperatura relacionando a concentração de formol e o equipamento.

Gráfico 8. Médias de temperatura do leite azedo e integro adicionados ou não de formol.

Gráfico 9. Médias da condutividade medida pelo equipamento controle utilizando-se diferentes concentrações de água e ureia adicionadas ao leite azedo e integro. _ 50 Gráfico 10. Médias da condutividade medida pelo equipamento protótipo utilizandose diferentes concentrações de água e ureia adicionadas ao leite azedo e integro. 51 


\section{Lista de Siglas e Abreviaturas}

ANVISA - Agencia Nacional de Vigilância Sanitária

BPF - Boas Práticas de Fabricação

CATI - Secretaria da Agricultura e Abastecimento de São Paulo:

Coordenadoria de Desenvolvimento Rural Sustentável.

CCS - Contagem de Células Somáticas

$\mathrm{CH}_{2} \mathrm{OH}-\mathrm{Formol}$

$\mathrm{CO}\left(\mathrm{NH}_{2}\right)_{2}$ ou $\mathrm{CH}_{4} \mathrm{~N}_{2} \mathrm{O}-$ Ureia

DVAGRO - Divisão de Produção Agropecuária

FAO - Food and Agriculture Organization of the United Nations (Organização das Nações Unidas para a Alimentação e a Agricultura)

FDA - Food and Drugs Administration

FZEA - Faculdade de Zootecnia e Engenharia de Alimentos

G-100 - Associação Brasileira das Pequenas e Médias Cooperativas e Empresas de Laticínio

$\mathrm{H}_{2} \mathrm{O}_{2}$ - Peróxido de Hidrogênio

IARC - International Agency for Research on Cancer (Agência Internacional de Pesquisa sobre o Câncer)

IBGE - Instituto Brasileiro de Geografia e Estatística

IDF - International Dairy Federation (Federação Internacional de Laticínios)

INCA - Instituto Nacional de Câncer José Alencar Gomes da Silva

IUPAC - International Union of Pure and Applied Chemistry (União Internacional de Química Pura e Aplicada)

MAPA - Ministério da Agricultura, Pecuária e Abastecimento

$\mathrm{NaOH}$ - Hidróxido de Sódio

$\mathrm{NH}_{3}-$ Amônia 
NUL - Nitrogênio Ureico no Leite

PARLPR - Laboratório da Associação Paranaense de Criadores da Raça Holandesa

PDCA - Plan, Do, Check, Act (Planejar, Fazer, Checar, Agir)

RBF - Redes Neurais de Base Radial

RIISPOA - Regulamento de Inspeção Industrial e Sanitária de Produtos de Origem Animal

RNA - Redes Neurais Artificiais

UHT - Ultra Hight Temperatura (Temperatura Ultra Alta) 


\section{Desenvolvimento de Sistema de Sensores para Identificação de Fraude no Leite Bovino}

\section{Resumo}

O leite é um produto de origem animal e, assim denominado, quando oriundo de vacas sadias em estado de lactação, é composto por água, proteínas, gorduras, minerais, carboidratos, vitaminas e outros sólidos solúveis e, a ele, não podem ser adicionadas substâncias estranhas nem conter resíduos de medicamentos e antibióticos. Possui shelf-life relativamente curto, que se reduz ao não ser armazenado ou manipulado adequadamente, o que por vezes leva à fraude por parte da cadeia produtiva de lácteos, com o intuito de aumentar o volume de leite, mascarar alterações físico-químicas que possam ter ocorrido e/ou reaproveitar produtos inadequados ao consumo. Dentre as substancias comumente adicionadas ao leite se encontram o peróxido de hidrogênio, o hidróxido de sódio, o formaldeído ou formol e a ureia combinada com a adição de água. A detecção dessa adição por vezes é lenta, em alguns casos, complexa e de alto custo. Tecnologias alternativas e de baixo custo, como as línguas eletrônicas e plataformas como o Arduino, tem sido muito estudadas para emprego em análise de alimentos para reduzir o tempo analítico e o custo das análises. Assim, o presente trabalho teve por objetivo desenvolver e validar um sistema eletrônico de sensores para mensurar características físico-químicas do leite por meio do processamento de dados para identificação de fraude. Os sensores utilizados neste trabalho foram de $\mathrm{pH}$, temperatura e condutividade, os quais foram comparados com os sensores padrões utilizados para essas mensurações. Para o peróxido de hidrogênio e para a combinação ureia e água, nas concentrações testadas, o equipamento não produziu resultados conclusivos, para os demais testes realizados os sensores apresentaram um desempenho mais relevante e, assim, pode-se concluir que, o equipamento desenvolvido precisa de alguns ajustes, os quais irão viabilizar, no futuro, o seu emprego para a identificação de fraudes em leite.

Palavras-chave: análise de alimentos; fraude em alimentos; leite; Arduino; sistema eletrônico. 


\section{Development of a sensors system for identify frauds in dairy products}

\section{Abstract}

Milk is an animal product and, as such, when derived from healthy lactating cows, is composed of protein, fat, minerals, carbohydrates, vitamins and other soluble solids. It may not be added to foreign substances or contain residues of medicines and antibiotics. However, it has a relatively short shelf life, it is reduced when not properly stored or have been inadequate handled, which sometimes leads to fraud by the dairy production chain in order to yield more milk, mask physicochemical changes that may have occurred and/or reuse products that are not suitable for consumption. Commonly added substances in milk include hydrogen peroxide, sodium hydroxide, formaldehyde or formaldehyde and urea combined with the addition of water. Detection of this addition is sometimes slow, in some cases complex and costly. Low cost alternative technologies such as electronic languages and platforms such as Arduino have been widely studied for use in food analysis to reduce analytical time and the cost of laboratory analysis. Thus, the present work aimed to develop and validate an electronic sensor system to measure physicochemical characteristics of milk by processing data to identify fraud. The sensors used in this work were $\mathrm{pH}$, temperature and conductivity, which compared with the standard sensors used for these measurements. For hydrogen peroxide and for the combination urea and water, at the tested concentrations, the equipment did not produce conclusive results, for the other tests performed, the sensors obtained a good performance and, therefore, it may concluded that the developed equipment needs some adjustments, which will make it possible for you to identify milk fraud in the future. Keywords: food analysis; food fraud; milk; Arduino; electronic system. 


\section{Sumário}

1. Introdução ___ 1

2. Revisão Bibliográfica ___ 4

2.1. O leite - definição e composição_______________ 4

2.2. O leite - Qualidade e legislação______ 8

2.3. Fraudes no leite - Casos recentes e fraudes mais comuns__ 10

2.4. Metodologias de análise ___ 12

2.5. Sistemas embarcados - definição e aplicações_____ 14

2.6. Caracterização dos adulterantes ___ _ 16

2.6.1. Hidróxido de Sódio — 16

2.6.2. Ureia__ 17

2.6.3. Formol 19

2.6.4. Peróxido de Hidrogênio___ 20

3. Materiais e Métodos _ 21

3.1. Materiais____ 21

3.2. Desenvolvimento e montagem do equipamento___ 22

3.3. Análises físico-químicas do leite ___ 24

3.4. Obtenção das soluções ___ 27

3.4.1. Hidróxido de Sódio _ 28

3.4.2. Peróxido de Hidrogênio___ 28

3.4.3. Formaldeído__ 28

3.4.4. Ureia e Água — 29

3.5. Obtenção das Medidas ___ 30

3.6. Análise estatística ___ 31

4. Resultados e Discussão ___ 32

4.1. Análise das características do leite puro e intencionalmente adulterado___ 32

4.1.1. Hidróxido de sódio 32

4.1.2. Peróxido de hidrogênio __ 40

4.1.3. Formaldeído__ 44

4.1.4. Ureia 49

5. Conclusão_ 52

6. Sugestões para Trabalhos Futuros ___ 53

Referências__ 54 


\section{Introdução}

O leite é considerado um dos mais completos alimentos e, apesar de se mostrar como produto homogêneo, seus constituintes principais equilibram-se de três maneiras distintas: as gorduras encontram-se em emulsão, em conjunto com as proteínas, que se encontram, em maior parte, como suspensão coloidal, ao mesmo tempo que algumas proteínas e os minerais encontram-se dissolvidos no soro aquoso (CRUZ et al., 2016).

Formado em maior parte por água, o leite ainda é composto por gordura, proteínas, carboidratos, minerais e traços de enzimas, visto que a primeira perfaz cerca de $87,3 \%$ da composição e os demais componentes sólidos $12,7 \%$, denominados sólidos totais (TRONCO, 2013). Alguns fatores influenciam naturalmente a composição do leite, como a raça, o ambiente, a idade do animal, o estágio de lactação, o manejo da ordenha, a sanidade e a nutrição do animal (CRUZ et al., 2016).

Segundo Cruz et al. (2017), o Brasil destaca-se como um dos maiores produtores de leite do mundo, produzindo em torno de 33 bilhões de litros de leite ao ano, no entanto o consumo de lácteos no país, em média, se encontra abaixo do recomendado pelo Ministério da Saúde. O consumo per capta recomendado é cerca de 200 litros por ano em três porções diárias, mas a média de consumo per capta no país é de 128 litros anuais, o que inclui o consumo de leite e derivados.

O RIISPOA - Regulamento de Inspeção Industrial e Sanitária de Produtos de Origem Animal - (BRASIL, 2017), coloca que o leite deve atender às seguintes especificações: cor, odor e aspecto normais, no mínimo 3,0\% de gordura, 2,9\% de proteína, 4,3\% de lactose, $8,4 \%$ de sólidos totais nãogordurosos, $11,4 \%$ de sólidos totais, acidez titulável entre 0,14 e 0,18 g ácido lático/100mL, densidade relativa a $15^{\circ} \mathrm{C}$ de 1,028 a $1,034 \mathrm{~g} / \mathrm{mL}$, índice crioscópico entre -0,530 e -0,555ํㅐ, sem adição de substâncias estranhas e sem resíduos de produtos veterinários ou contaminante acima do especificado por lei.

O leite que apresenta adição de substâncias estranhas, ou mesmo, adição de substâncias que o compõe, com a intenção de aumentar o volume, mascarar 
a acidez, reconstituir o nível de proteína ou paralisar a ação microbiana, por exemplo, é considerado um leite fraudado.

A detecção de produtos fraudados e de baixa qualidade tem sido cada vez mais necessária diante do desafio mundial de qualidade de alimentos. Leites fraudados podem causar prejuízos à indústria devido à redução do rendimento de alguns produtos, a redução do seu valor nutricional, alteração da qualidade dos derivados, além do risco à saúde do consumidor devido à adição de substâncias adulterantes, como agentes antimicrobianos, reconstituintes de densidade e neutralizantes de acidez (ABRANTES et al., 2014).

As análises físico-químicas clássicas consistem em provas de determinação de acidez, de densidade, teor de gordura, extrato seco total, determinação de ponto de congelamento e determinação de índice de refração (TRONCO, 2013). As principais preocupações em torno das características físico-químicas do leite estão relacionadas com o estado de conservação, a eficiência do tratamento térmico e integridade, em especial referente à adição ou remoção de substâncias, componentes ou não, do leite (ABRANTES et al., 2014).

Infelizmente, diversos casos de adulteração do leite têm sido denunciados e elucidados nos últimos anos. Mesmo proibido por lei, a adição de substâncias estranhas é um recurso muito utilizado na cadeia produtiva do leite. Tal prática pode acarretar prejuízos no processamento, além de danos econômicos e à saúde do consumidor (NAZÁRIO et al., 2009), que podem abranger de tonturas a fatores carcinogênicos, por exemplo. Dessa forma, quanto antes feita a identificação dessas fraudes, melhor.

A adição de água ao leite, com o intuito de aumentar seu volume, é uma das fraudes mais comuns e recorrentes, sendo que em alguns casos chegam a ser adicionados $10 \%$ de água, que se tornam quase imperceptíveis às análises convencionais. Essa prática ainda prejudica a qualidade microbiológica do leite, visto que a água utilizada normalmente não é tratada, além disso outros líquidos como soro de queijo e até mesmo a urina também são usados para o mesmo fim (FAGNANI, 2016). 
Substâncias que impedem e/ou retardam as alterações físico-químicas em alimentos pela ação de microrganismos ou enzimas, chamadas conservadoras, tem seu uso restrito na cadeia láctea, sendo permitido em alguns casos, como no uso de nitratos e sorbatos na produção de queijos. Nas demais situações são adicionados fraudulentamente para aumentar a vida útil do leite, como a adição de peróxido de hidrogênio, carbonatos e cloraminas, por exemplo (G-100, 2018).

Outra fraude recorrente é a adição de formol e peróxido de hidrogênio com o intuito de paralisar a atividade microbiana, quando apresentam alteração de pH e acidez Dornic elevada, por conta da alta carga de micro-organismos ali presentes. O uso de reconstituintes de densidade são outra fraude muito comum, onde, em geral, pode-se observar a adição de substâncias como amido, sacarose, urina e ureia (ABRANTES et al., 2014).

O uso de formaldeído ocasiona um enrijecimento das proteínas, o que dificulta sua digestão, além de causar danos gástricos e às enzimas digestivas, já o peróxido de hidrogênio é notado pelo sabor estranho e relativa adstringência e, em concentrações elevadas, pode ocasionar queimaduras nas mãos e cavidade bucal (G-100, 2018).

Em 2017 foram identificados uso de água, hidróxido de sódio e outras substâncias adulterantes no leite e no creme de leite por alguns laticínios, no Rio Grande do Sul, parte da $12^{a}$ etapa da Operação Leite Compensado (LEHMEN, 2017). Anteriormente, foram deflagradas fraudes devido à adição de peróxido de hidrogênio, hidróxido de sódio e álcool etílico em Santa Catarina e, adição de água, sal, açúcar, soro de leite e amido ao leite, além de alta acidez no Rio Grande do Sul (MAPA, 2014; LARA, 2015).

A literatura mostra que é possível desenvolver um sistema que identifique a adição de substâncias adulterantes no leite de forma simples, rápida e barata assim, visto que existem tecnologias nessa linha podem ser utilizadas.

Nascimento et al. (2010) colocam que a condutividade elétrica (EC) pode ser um método simples e barato para verificar a presença de hidróxido de sódio, água e cloreto de sódio em leite. Outra opção bastante interessante é a língua 
eletrônica, que engloba a utilização de sensores eletroquímicos, ópticos ou enzimáticos (DI ROSA et al., 2017).

As línguas eletrônicas já foram empregadas para classificar bebidas de frutas e leite (WINQUIST et al., 1997 apud DI ROSA et al., 2017), para detectar vestígios de pesticidas organofosforados (FACURE et al., 2017) e para caracterizar cafés expressos produzidos utilizando diferentes perfis térmicos, por exemplo (BURATTI, BENEDETTI \& GIOVANELLI, 2017).

Os sensores podem ser utilizados em sistemas embarcados, que vêm como uma opção para ajudar nesse processo analítico que, baseado nas tecnologias já existentes, podem trazer um conceito novo de utilização destas de forma mais eficiente, simples e muitas vezes de baixo custo.

Uma das opções para controlar esses sistemas de forma simples é a utilização da placa micro controladora Arduino, criada para ser uma ferramenta de prototipagem rápida direcionada para estudantes com restrito conhecimento na área da eletrônica e programação, sendo, hoje, um dos principais ecossistemas de software e hardware de código aberto do mundo, muito popular para o desenvolvimento de produtos loT (Internet of Things) (ARDUINO, 2018).

O presente trabalho tem como objetivo desenvolver um sistema eletrônico de sensores que seja capaz de identificar a presença de hidróxido de sódio $(\mathrm{NaOH})$, formol $\left(\mathrm{CH}_{2} \mathrm{O}\right)$, ureia $\left(\mathrm{CH}_{4} \mathrm{~N}_{2} \mathrm{O}\right)$ e peróxido de hidrogênio $\left(\mathrm{H}_{2} \mathrm{O}_{2}\right)$ no leite, que seja de baixo custo, leve e portátil para ser utilizado em qualquer elo da cadeia produtiva do leite que apresente resultados imediatos, confiáveis e precisos, para que gerem dados seguros e permitam a prévia identificação dos casos de fraude, visando o melhor processamento do leite, redução das perdas nos laticínios, além de assegurar a qualidade dos produtos, a segurança alimentar e saúde do consumidor.

\section{Revisão Bibliográfica}

\subsection{O leite - definição e composição}

O Codex Alimentarius foi criado em 1963 como um programa conjunto da Organização das Nações Unidas para Agricultura e Alimentação (FAO) e da Organização Mundial da Saúde (OMS), para estabelecer normas internacionais 
na área de alimentos, como padrões de identidade e qualidade, diretrizes e guias de Boas Práticas, bem como de Avaliação de Segurança e Eficácia com o intuito de proteger a saúde dos consumidores e garantir práticas leais de comércio entre os países. Essas normas são de aplicação voluntária, mas em diversos casos são tidos como referências para a legislação do país. O Codex é composto por 187 países membros e União Europeia, conta com 238 observadores (57 organizações intergovernamentais, 165 organizações não governamentais e 16 organizações das Nações Unidas) (ANVISA, 2016). O Codex Alimentarius (Codex Stan 206, 1999), de tal forma, especifica leite por:

O leite é a secreção mamaria normal da ordenha de animais obtidos a partir de um ou mais ordenhas, sem qualquer adição a isso ou extração a partir dele, destinada ao consumo como leite líquido ou para processamento adicional.

A FDA - Food and Drugs Administration é um órgão do Departamento de Saúde e Direitos Humanos (Departure of Health and Human Services) dos Estados Unidos da América que regulamenta alimentos, medicamentos, produtos biológicos e cosméticos, por exemplo (FDA, 2018). O leite é definido na normativa da FDA (2016) como:

O leite é a secreção láctea, praticamente livre de colostro, obtida pela ordenha completa de uma ou mais vacas saudáveis. O leite que esteja na forma de embalagem final para uso de bebidas deve ter sido pasteurizado ou ultrapasteurizado e deve conter, pelo menos, 8 11/4 por cento de sólidos não gordurosos e pelo menos $31 / 4$ por cento de sólidos gordurosos.

Existem diversas definições dadas ao leite, a legislação brasileira pelo RIISPOA (BRASIL, 2017) diz "entende-se por leite, sem outra especificação, o produto oriundo da ordenha completa, ininterrupta, em condições de higiene, de vacas sadias, bem alimentadas e descansadas".

Cruz et al. (2016) ainda colocam duas outras definições de leite, a primeira o coloca como uma "emulsão de coloração branca, ligeiramente amarelada, de odor suave e sabor adocicado". A segunda, apresenta o leite de uma perspectiva 
mais química, assim definido por uma "suspensão coloidal de caseína, emulsão de glóbulos de gordura e solução de lactose, proteínas do soro e sais minerais".

Segundo Koblitz (2011) a composição do leite é água, sólidos totais, gordura, proteínas, lactose e minerais, como descrito na Tabela 1. Ainda consonante a autora, sua composição pode variar de acordo com fatores genéticos, incluindo espécie e raça, por exemplo, aspectos fisiológicos, como idade, período de lactação, ocorrência de doenças, bem como por fatores ambientais e de manejo, dentre eles, clima, estação do ano, temperatura, chuvas, incidência solar e alimentação.

Tabela 1. Composição do Leite.

\begin{tabular}{cccc}
\hline \multirow{2}{*}{ Componente } & \multicolumn{2}{c}{ Limite da variação (\%) } & $\begin{array}{c}\text { Valor } \\
\text { médio (\%) }\end{array}$ \\
\cline { 2 - 3 } & mín. & máx. & 87,5 \\
Água & 85,5 & 89,5 & 13,0 \\
Sólidos totais & 10,5 & 14,5 & 3,9 \\
Gordura & 2,5 & 6,0 & 3,4 \\
Proteínas & 2,9 & 5,0 & 4,8 \\
Lactose & 3,6 & 5,5 & 0,8 \\
Minerais & 0,6 & 0,9 & \\
\hline
\end{tabular}

Fonte: Adaptado de Koblitz (2011).

Cruz et al. (2019) caracterizam a composição do leite como $87,1 \%$ de água; $4,6 \%$ de carboidratos - lactose; $4 \%$ de lipídeos - mono, di e triglicerídeos, fosfolipídeos, cerebrosídeos etc.; $3,25 \%$ de proteínas - caseínas, $\beta$ lactoglobulina, $\alpha$-lactoalbumina, soroalbumina, entre outras; $0,7 \%$ de minerais cálcio, magnésio, potássio, sódio e outros; 0,19\% de ácidos orgânicos - cítrico, fórmico, acético, lático etc.; Teores menores de vitaminas do complexo B, ácido ascórbico, aminoácidos, ureia, amônia e outros.

As proteínas do leite se dividem, basicamente, em dois grupos: as proteínas do soro e as caseínas. A proporção das proteínas do soro frente a caseína varia de acordo com o estado de lactação do animal, entretanto, as caseínas, que contém fosfato, constituem mais de $80 \%$ do total de proteínas. Essas se dividem em cinco tipos, sendo eles $\alpha_{\mathrm{s} 1}, \alpha_{\mathrm{s} 2}, \beta$, $\gamma$ e $\mathrm{k}$, elas se precipitam quando o $\mathrm{pH}$ do leite atinge 4,6, assim o sobrenadante contém as proteínas do soro do leite: $\beta$-lactoglobulina e $\alpha$-lactoalbumina (VENTURINI FILHO et al., 2010). 
A lactose é o principal carboidrato encontrado no leite, presente em todos os tipos, é um dissacarídeo redutor formado por uma D-galactose e uma Dglicose, unidas por uma ligação glicosídica tipo $\beta-1,4$ (Figura 1) e pode se apresentar de duas formas isométricas, $\alpha$ - e $\beta$-lactoses. Compõe cerca de 37 a $54 \mathrm{~g} / \mathrm{l}$ do leite, no caso do bovino, de 45 a $50 \mathrm{~g} / \mathrm{L}$, esse açúcar não se encontra totalmente em solução no leite, visto que em torno de $11,0 \%$ dele se encontram associados às proteínas. Possui um suave sabor adocicado e tem baixo poder adoçante, que no leite, por vezes é mascarado pela presença das caseínas (KOBLITZ, 2011).

Figura 1. Estrutura da a-Lactose.

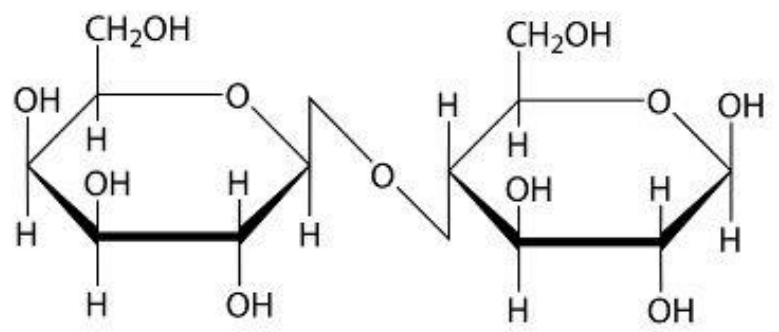

Fonte: KOBLITZ (2011).

Segundo Cruz et al. (2016) e Venturini Filho et al. (2010), a gordura do leite é composta de uma mistura de compostos insolúveis em solventes aquosos. O leite bovino apresenta $98 \%$ de triacilgliceróis e, contém também diacilgliceróis, monoacilglicerol, fosfolipídeos, ácidos graxos livres, cerebrosídeos, gangliosídeos, colesterol e ésteres de colesterol, bem como vitaminas lipossolúveis como as vitaminas $A, E, D$ e K. Apresentam, também, alguns componentes em quantidades muito pequenas, mas que impactam diretamente as propriedades sensoriais do leite, como aldeídos, cetonas e lactonas. A Tabela 2 apresenta a composição de lipídeos do leite de duas espécies.

O leite apresenta diversas vitaminas, as lipossolúveis $A, D, E$ e $K$, por exemplo e as hidrossolúveis $B_{1}$ (tiamina), $B_{2}$ (riboflavina), $B_{3}$ (niacina), $B_{5}$ (ácido pantotênico), $B_{6}$ (piridoxina) e $B_{12}$ (cianocobalamina). Apresenta ainda diversos minerais, mesmo que em quantidade pequena, tem papel essencial do ponto de vista nutricional. Os minerais presentes em maior quantidade são cálcio, magnésio, fosfatos, cloro, fósforo, citratos, cloretos, sulfatos e bicarbonatos de sódio e de potássio. Outros elementos como cobre, ferro, boro, manganês, zinco 
e iodo, chamados oligoelementos, também fazem parte do leite em quantidades ainda menores que os minerais (KOBLITZ, 2011).

Tabela 2. Composição dos lipídios de duas espécies.

\begin{tabular}{ccc}
\hline \multirow{2}{*}{ Lipídio } & \multicolumn{2}{c}{$\%$ total de lipídios } \\
\cline { 2 - 3 } & Vaca & Humano \\
\hline Triglicerídeos & $97-98$ & 98,2 \\
\hline Diglicerídeos & $0,25-0,48$ & 0,7 \\
\hline Monoglicerídeos & $0,02-0,04$ & Traços \\
\hline Ácidos Graxos Livres & $0,1-0,4$ & 0,4 \\
\hline Fosfolipídios & $0,6-1,0$ & 0,25 \\
\hline Colesterol & $0,2-0,4$ & 0,25 \\
\hline Ésteres do colesterol & Traços & Traços \\
\hline
\end{tabular}

Fonte: Cruz et al., 2016.

\subsection{O leite - Qualidade e legislação}

O G-100 - Associação Brasileira das Pequenas e Médias Cooperativas e Empresas de Laticínios - na publicação Lácteos Seguros (2018) coloca que o leite produzido no Brasil, pode ser consumido em todo o mundo. Assim, a qualidade se torna cada dia mais importante.

No entanto, no Brasil isso se torna um desafio devido às suas dimensões, visto que nem toda a extensão rural brasileira recebe energia elétrica, muitas estradas são extremamente desgastadas ou nem existem e, por esses e muitos outros motivos, o leite pode acabar demorando para ser recolhido e alguns produtos frescais podem perder qualidade por práticas de conservação inadequada.

A segurança e qualidade dos alimentos são de responsabilidade das empresas do setor, a partir da década de 80 os critérios microbiológicos auxiliaram no desenvolvimento de padrões internacionais de higiene alimentar. A prática de medidas que permitam o controle da entrada de qualquer agente que possa ocasionar risco à integridade física ou à saúde do consumidor é denominada segurança de alimentos, abrange desde a produção agrícola até a mesa (DE LIMA, 2018). 
Em 1999 introduziu-se a abordagem baseada na avaliação do risco microbiológico no Codex Alimentarius, revisada em 2007 por uma Comissão do Codex onde se propôs uma abordagem baseada em gestão da segurança alimentar, estabelecendo-se objetivos de segurança alimentar e de desempenho, bem como os seus respectivos critérios. O setor de laticínios tem se apropriado de tal abordagem para garantir a segurança e qualidade do leite, monitorando a evolução da legislação alimentar, regulamentações, métodos analíticos e avaliação de riscos (IDF, 2014).

O controle de qualidade do leite se inicia no manejo, quando utilizadas boas práticas de fabricação (BPF) nessa etapa, podem garantir que o leite seja seguro e adequado ao que se destina, bem como que a empresa rural permaneça viável econômica, social e ambientalmente. As BPF aplicadas à pecuária leiteira apoiam sua produção e garantem a satisfação das altas expectativas da indústria e dos consumidores (FAO e IDF, 2013).

A legislação brasileira se pauta nos requisitos de qualidade e segurança de alimentos internacionalmente estabelecidos, assim o RIISPOA (BRASIL, 2017) e a Instrução Normativa № 76/2018 (BRASIL, 2018), o leite, para que assim seja considerado, além de obedecer à definição de leite já citada, também deve atender aos padrões físico-químicos estabelecidos pela legislação, não apresente substâncias adulterantes como agentes neutralizantes de acidez, inibidores de crescimento microbiano, reconstituintes de densidade ou de índice crioscópico, bem como não contenha resíduos de drogas veterinárias e outros contaminantes.

A mesma instrução normativa determina que o limite das médias geométricas trimestrais da contagem de células somáticas (CCS) no leite deve ser de $500.000 \mathrm{CS} / \mathrm{mL}$ no leite cru refrigerado de tanque individual ou comunitário e proíbe o uso de aditivos ou coadjuvantes de tecnologia no leite cru.

A CCS é aumentada pela incidência de mastite no rebanho. A mastite é uma doença infecciosa aguda ou crônica do úbere que afeta as glândulas mamárias de fêmeas lactantes, o que compromete as características físicoquímicas e implica no aumento da CCS (Contagem de Células Somáticas) no leite e, consequentemente, tem relação direta com a queda de produtividade, 
alterações na composição do leite, na atividade enzimática, no tempo de coagulação, no rendimento industrial e na qualidade de seus derivados. Pode ser provocada ou agravada por traumatismos internos e externos, ordenhadeira desregulada e/ou não desinfetada, falhas ou ausência de assepsia dos tetos antes da ordenha, ordenha manual traumatizante, bem como hábitos de higiene inadequados do ordenhador (BAGGIO; MONTANHINI, 2017; CATI, 2019).

\subsection{Fraudes no leite - Casos recentes e fraudes mais comuns}

Cruz et al. (2019) descrevem que a adição de água ao leite, com o objetivo de aumentar o volume e a lucratividade dos produtores, é quase tão antiga quanto sua origem, cerca de 6 a 8 mil anos a.C.. Facilmente identificada pela crioscopia, que consiste na análise do ponto de congelamento do leite, e até mesmo pela análise da densidade, com uma sensibilidade um pouco menor.

Infelizmente, tem-se tido cada vez mais notícias de fraudes no leite, por exemplo, em 2013/2014, onde foi deflagrado um esquema de fraude no leite em Santa Catarina, com a adição de peróxido de hidrogênio, hidróxido de sódio e álcool etílico. Esses aditivos costumam ser utilizados para mascarar problemas de qualidade ou manter o padrão de qualidade exigido (MAPA, 2014).

No Rio de Janeiro, segundo o site G1 (2014), três marcas tiveram a venda suspensa por adição de formol ao leite UHT, visto que o Procon Carioca recebeu diversas denúncias de consumidores, bem como foram registrados casos de intoxicação alimentar, com sintomas como dores abdominais e náuseas, por ingestão dos mesmos. $\mathrm{O}$ recall dos lotes contaminados foi realizado pelo órgão.

Mandados de prisão preventiva, prisão cautelar e busca e apreensão foram executados no Rio Grande do Sul em 2015 pelo Ministério Público devido à identificação de fraudes no leite por adição de água ao leite cru refrigerado pela transportadora, como também adições de sal, açúcar, soro de leite e amido, além de alta acidez, caracterizando deterioração do produto (LARA, 2015).

As investigações apontaram que o proprietário da empresa de transportes e mais quatro motoristas eram responsáveis por adicionar substâncias como bicarbonato de sódio ao leite cru que, em grande parte das vezes, já se 
encontrava inadequado ao consumo, com o intuito de aumentar o volume do produto final, evitar a perda de leite por deterioração e ser aprovado nos testes laboratoriais das indústrias (G1-RS, 2015).

Em 2017, pela 12 ${ }^{\mathrm{a}}$ fase da Operação Leite Compensado, foi deflagrada mais uma fraude no Rio Grande do Sul, onde, segundo o Ministério Público, as indústrias utilizavam água e substâncias como hidróxido de sódio para reutilizar produtos vencidos. Em alguns laticínios além de fraudes no leite, foram identificadas também fraudes no creme de leite (LEHMEN, 2017).

Em Santa Catarina, em 2018, a justiça condenou 16 pessoas por fraudes e adulterações no leite. A empresa adicionava hidróxido de sódio ao leite cru para mascarar os defeitos de qualidade do produto que era distribuído em SC, RS e SP. As condenações foram por adulteração de produtos alimentícios, crimes contra as relações de consumo e falsidade ideológica (CORREIO DO POVO, 2018).

As consequências das adulterações no leite são tão graves que, na Índia em 2008, cinco crianças morreram após ingerir leite adulterado em um colégio público de Jharkhand (Índia), outras sessenta crianças ficaram doentes, sendo dezenove em estado grave (G1.COM, 2008).

No Brasil, a adulteração de leite pode levar à prisão, como ocorreu na Operação Leite Compensado, mas em outros países como a China, por exemplo, em 2009 duas pessoas foram condenadas à morte por esse crime, quando a adição de melamina ao leite provocou a morte de seis crianças e deixou cerca de 300 mil doentes (ESTADÃO INTERNACIONAL, 2009).

A inserção de diversos perigos químicos ao leite e seus derivados pode ocorrer durante toda sua cadeia produtiva de forma intencional ou não, incluindo desde substâncias de origem natural com potencial tóxico, como as micotoxinas, de origem ambiental como as dioxinas e metais, formadas no processamento do leite ou até mesmo aditivos específicos e adulterantes. As principais formas de contaminação estão apresentadas na Figura 2. A presença de substâncias potencialmente tóxicas pode ocasionar reações agudas (curto prazo) ou crônicas (longo prazo) na população consumidora, de acordo com a dose e seus hábitos de consumo (CRUZ et al., 2016). 
Figura 2. Principais rotas de contaminação química do leite.

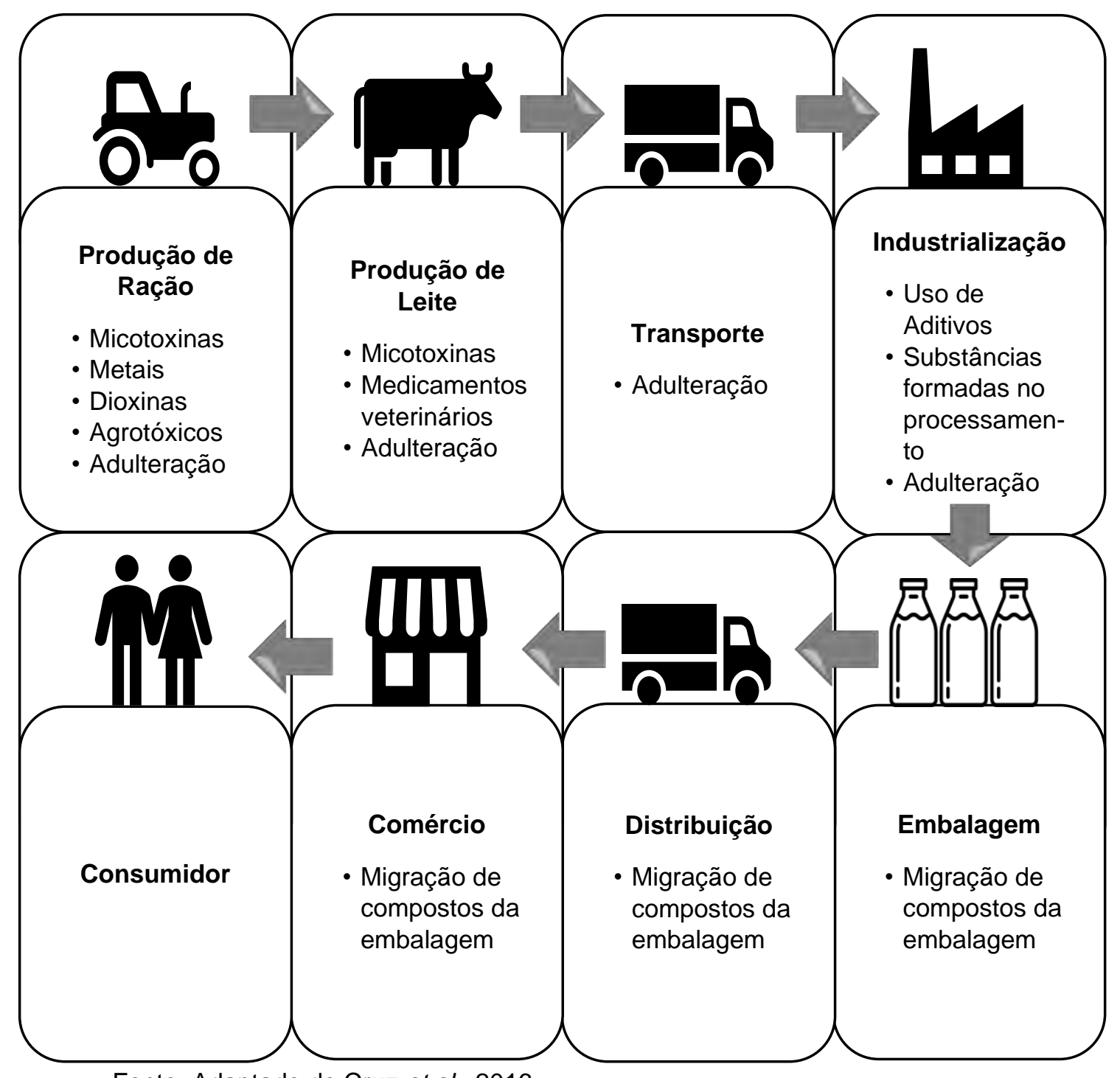

Fonte: Adaptado de Cruz et al., 2016.

\subsection{Metodologias de análise}

Dentre os testes convencionalmente utilizados para controle físicoquímico do leite, pode-se citar as provas do alizarol, do álcool e o processo Dornic para a determinação de acidez, a determinação de densidade (por tabela, cálculos teóricos e balança de Westfall), além das determinações de gordura, extrato seco total, extrato seco desengordurado, ponto de congelamento e índice de refração (TRONCO, 2013).

A identificação da adição de água, por exemplo, pode ser feita pela análise de densidade e do ponto de congelamento crioscópico. Quando ocorre esse tipo 
de fraude, a primeira se reduz e a segunda se eleva, já o desnate do leite e adição de amido fazem o efeito inverso. A adição de alcalinos pode diminuir a acidez e/ou aumentar o tempo de conservação, pode indicar falhas nas práticas higiênico-sanitárias no manejo, ordenha e conservação do leite cru. Outras fraudes que podem ocorrer são a adição de conservantes, reconstituintes de densidade, de soro de queijo e de rotulagem (ABRANTES et al., 2014).

Valente et al. (2014) analisaram a viabilidade de utilizar as redes neurais artificiais (RNA) para detecção de fraude em leite pela adição de soro de leite baseados nas análises de rotina de um laticínio e obtiveram seus melhores resultados utilizando uma rede neural de base radial (RBF), com dez neurônios na camada de entrada, quarenta na oculta e dois na camada de saída, obtendo 95\% de acertos na classificação.

Nascimento et al. (2017) listaram os mais recentes avanços na identificação de adulterantes no leite, relacionando por tipo e por grau de dificuldade de preparo de amostras, onde pode-se observar a utilização de métodos como sensores e espectroscopia de Infravermelho para identificação de fraudes.

Além dessas, a utilização de sistemas como a língua eletrônica tem sido estudada nos últimos anos. Zou et al. (2015) colocam que a teoria da língua eletrônica se baseou em mecanismos do sistema gustativo humano e que podem ser consideradas como instrumentos analíticos capazes de reproduzir artificialmente o paladar e, se bem configurada e calibrada, podem identificar a composição qualitativa e quantitativa de soluções multi-espécies de diferentes naturezas.

O relatório técnico da IUPAC (VLASOV et al, 2005) define língua eletrônica da seguinte forma:
A língua eletrônica é um instrumento analítico que compreende uma matriz de sensores químicos inespecíficos, pouco seletivos, com alta estabilidade e sensibilidade cruzada para diferentes espécies em solução, e um método apropriado de PARC e/ou calibração multivariada para processamento de dados. 
A língua eletrônica engloba a utilização de sensores eletroquímicos, ópticos ou enzimáticos, também chamados biossensores (DI ROSA et al, 2017). Segundo Souza (2015), pode-se definir sensor como um dispositivo capaz de reagir a alguma variação física externa e torná-la um sinal mensurável.

Ainda consonante ao autor, sensores eletroquímicos são sensores onde a informação química do meio obtida pelo receptor é transformada em sinal elétrico pelo transdutor e, acrescenta que eles podem ser divididos em três subcategorias: sensores potenciométricos, amperométricos e condutimétricos, que detectam potencial, corrente elétrica e condutividade ou resistividade, respectivamente.

\subsection{Sistemas embarcados - definição e aplicações}

Os Sistemas Embarcados (Embedded Systems) são sistemas computacionais independentes, completos, mais simples do que um computador convencional e, em geral, destinados a executar tarefas específicas e prédefinidas. Também conhecido como sistema embutido, são compostos basicamente por componentes de um computador pessoal, mas seu tamanho e capacidade são limitados ao seu propósito (dos SANTOS; MORENO, 2018).

Andrade et al. (2016) colocam que tal conceito surgiu com o intuito de atingir o crescente mercado da miniaturização dos dispositivos, executando aplicações de software em uma plataforma de hardware distintas das corriqueiras. Segundo o Barr (2019), sistemas embarcados podem ser definidos como a combinação entre hardware e software e, por algumas vezes, mecânicas ou outras peças extras com o objetivo de executar uma ação dedicada, bem como pode fazer parte de um sistema ou produto maior.

Os sistemas embarcados estão cada vez mais presentes em aplicações cotidianas, sejam elas robóticas e autônomas ou mesmo em equipamentos de como fornos de micro-ondas, telefones celulares, calculadoras, e com aplicação ao desenvolvimento de novos produtos (DOS SANTOS; MORENO, 2018). Consonante a Andrade et al. (2016), uma das plataformas que se tem utilizado frequentemente para o desenvolvimento desses sistemas, é o Arduino. 
O Arduino é uma plataforma eletrônica de código aberto que consiste em hardware e software de fácil manipulação, onde se pode dizer à placa o que fazer por meio de um conjunto de instruções para seu microcontrolador, usando uma linguagem de programação Arduino e o software Arduino (IDE), baseado em processamento. Nascido no Ivrea Interaction Design Institute (França), o Arduino foi criado para ser uma ferramenta fácil, com rápida prototipagem, destinada a estudantes sem formação em eletrônica e programação (ARDUINO, 2018).

Usado na criação de protótipos, o Arduino possui capacidade de desenvolvimento fácil e rápida, e é mais conhecido por seu hardware. Seu software é gratuito, de código aberto e de plataforma cruzada. Tanto o software quanto hardware são denominados Arduino (KUMAR et al., 2013).

Existem várias versões do Arduino, as mais comuns entre elas são o Arduino Nano, o Arduino Uno, o Lilypad e o Arduino Mega (BARROS, 2018). O Arduino Nano (Figura 3a) é uma placa compacta, completa, de uso simples e utiliza um cabo USB Mini-B ao invés do cabo padrão, já o Uno (Figura 3b) é bastante semelhante em termos de configuração, no entanto é uma placa mais robusta, ideal para iniciantes. O Arduino Lilypad (Figura 3c) foi desenvolvido para ser utilizado em roupas e tecidos, pode ser costurado a eles e utiliza fontes de alimentação com fios condutores, o Mega (Figura 3d), por sua vez, foi projetado para projetos mais complexos, recomendado para projetos de robótica e desenvolvidos com impressora 3D (ARDUINO, 2019a; ARDUINO, 2019b; ARDUINO, 2019c; ARDUINO, 2019d).

A literatura registra vários avanços do uso do Arduino para desenvolvimento de equipamentos de menor custo e dimensão. Skoczek et al. (2019) propõe um sistema de análise de fluxo por multibombeamento totalmente automatizado (Multi-Pumping Flow Analysis - MPFA) controlado por Arduino para determinar a atividade de $\beta$-galactosidase, enquanto Avallone et al. (2019) propõem a construção de um anemômetro de baixo custo utilizando Arduino, já Yang et al. (2019) propõem a sua utilização na construção de um dispositivo portátil e de baixo custo para medir o conteúdo de metano das amostras de biogás. 
Figura 3. Tipos de Arduino: (a) Arduino Nano; (b) Arduino Uno; (c) Arduino LilyPad; (d) Arduino Mega.

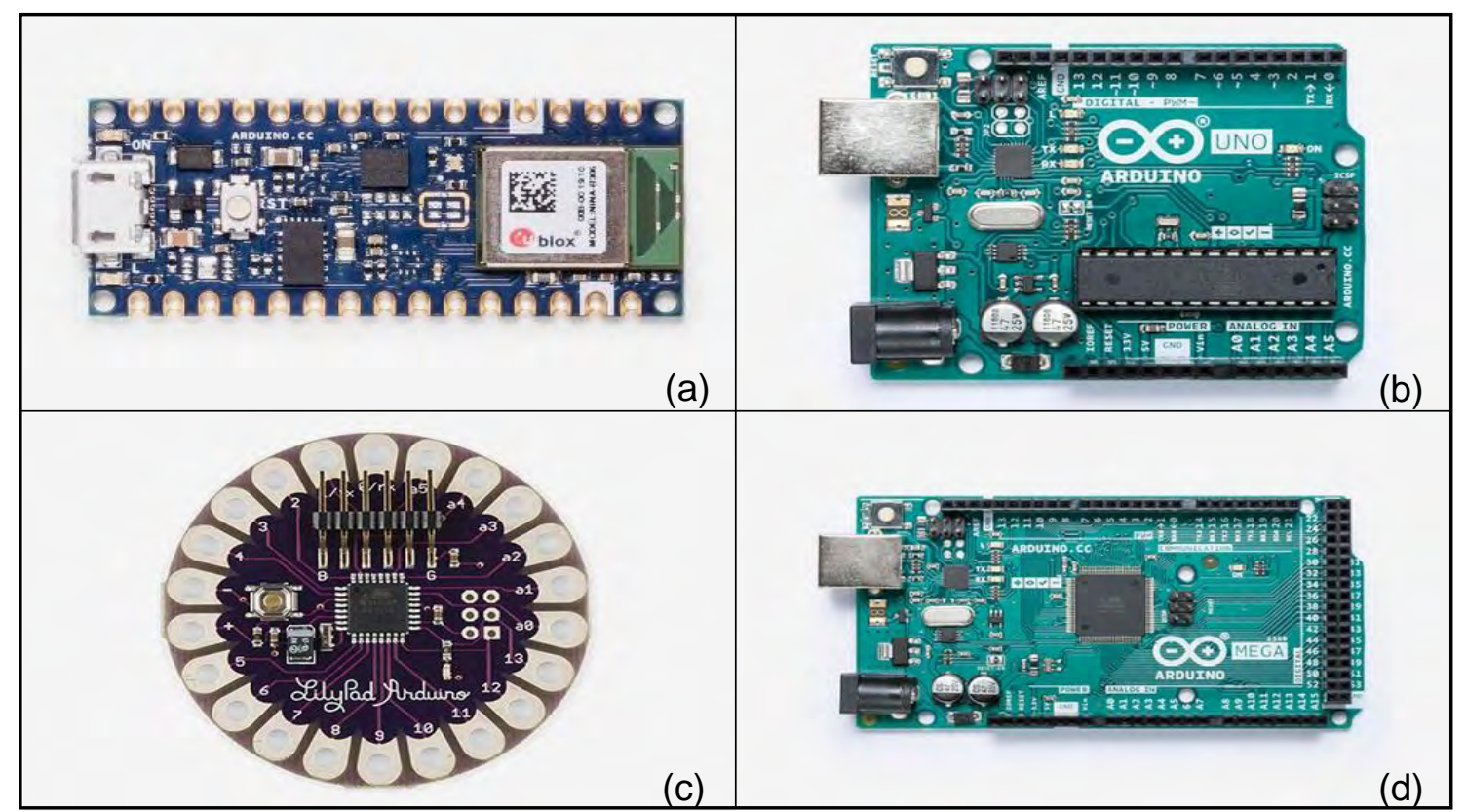

Fontes: (a) ARDUINO (2019a); (b) ARDUINO (2019b); (c) ARDUINO (2019c); (d) ARDUINO (2019d).

Entrando na área alimentícia é possível notar a criação de eletrodomésticos capazes de se conectarem entre si e compartilharem informações tornando o ambiente mais adequado ao usuário, como fizeram Manuel et al. (2019) que desenvolveram um gabinete inteligente para alimentos que podia informar aos usuários seu conteúdo por meio de um aplicativo móvel, além de combinar seus próprios dados e fornecer uma seleção de receitas de acordo com os itens ali disponíveis.

\subsection{Caracterização dos adulterantes}

\subsubsection{Hidróxido de Sódio}

O hidróxido de sódio é um sólido inodoro, branco, cristalino e altamente higroscópico, que ao ser dissolvido em água ou neutralizado com ácido, provoca uma reação exotérmica. A solução de hidróxido de sódio é um líquido incolor, mais denso que a água, tóxico por ingestão e corrosivo para metais e tecidos, geralmente presente em limpadores comerciais de drenos e fornos (NATIONAL CENTER FOR BIOTECHNOLOGY INFORMATION, 2019a). 
O hidróxido de sódio $(\mathrm{NaOH})$ pode ser utilizado, segundo a legislação brasileira (ANVISA, 2018), como aditivo para regular a acidez de alguns alimentos a um limite de $0,2 \mathrm{~g} \mathrm{NaOH} / 100 \mathrm{~g}$. No entanto, para o leite o MAPA Ministério da Agricultura, Pecuária e Abastecimento - por meio do RIISPOA (Regulamento de Inspeção Industrial e Sanitária de Produtos de Origem Animal) coloca que para ser assim denominado deve atender características físicoquímicas específicas e não apresentar substâncias estranhas à sua composição, bem como não apresentar resíduos de produtos veterinários ou contaminantes acima do previsto em normas complementares (BRASIL, 2017).

De tal maneira, o hidróxido de sódio por sua característica de ser regulador de acidez é utilizado como adulterante no leite, previsto na lei brasileira, mas não permitido para o leite e produtos lácteos (ANVISA, 2007a).

Um dos requisitos físico-químicos, que são parte dos padrões de identidade e qualidade estabelecido pelo MAPA, é a acidez em ácido láctico, que deve se encontrar entre 0,14 e 0,18g de ácido lático/ $100 \mathrm{~mL}$ (BRASIL, 2017). A acidez fora do limite permitido tem relação com a contagem de bactérias, que são consequência da ausência ou deficiência de boas práticas durante a produção e o processamento do leite. Dessa maneira, como forma de fraude, se utiliza da adição do hidróxido para que a acidez do leite seja corrigida, o que coloca em risco à saúde do consumidor principalmente quanto a carga bacteriana, que é o agente causador da acidez do leite (ANVISA, 2007b).

O hidróxido de sódio, vulgarmente denominado soda cáustica, quando ingerido pode provocar dor intensa na boca, garganta, região retroesternal e estômago, com espasmo reflexo da glote, edema e inflamação na boca, faringe posterior e laringe que levam a redução do calibre das vias aéreas, propiciando o surgimento de complicações pulmonares. A ingestão de produtos líquidos pode ocasionar lesões esofágicas sem lesão da boca ou da faringe (OGA, 2008).

\subsubsection{Ureia}

A ureia é um composto nitrogenado que contém um grupo carbonila ligado a dois grupos amina com atividade diurética osmótica e, in vivo, é formada no fígado a partir da amônia e é o produto final do metabolismo das proteínas. A ingestão pode causar aumento da osmolaridade do plasma sanguíneo, 
intensificando o fluxo de água dos tecidos, diminuindo a pressão nesses e aumentando a saída de urina. A ureia é uma amida de ácido monocarboxílico derivada de um ácido carbônico encontrada como cristais ou granulados brancos inodoros sólidos, muito solúvel em água e etanol (NATIONAL CENTER FOR BIOTECHNOLOGY INFORMATION, 2019b).

Os fertilizantes nitrogenados são os mais utilizados na agricultura, visto que o nitrogênio apresenta alta mobilidade no solo, alto índice salino dos adubos que o contém. Dentre esses, os mais frequentemente aplicados são a ureia, o sulfato de amônio, o nitrato de amônio e a solução líquida uran. A ureia $\left(\mathrm{CO}\left(\mathrm{NH}_{2}\right)_{2}\right)$ contém $45 \mathrm{~g}$ de nitrogênio $(\mathrm{N}) / \mathrm{kg}$ apresenta alta higroscopicidade e, por isso, seus grânulos são revestidos de material protetor, além de solubilidade de $1000 \mathrm{~g} / \mathrm{L}$ a $20^{\circ} \mathrm{C}$ (SOUZA et al, 2011).

A ureia, além de fertilizante, é um componente presente no leite que pode indicar o estado nutricional do rebanho, ele é denominado NUL (Nitrogênio Uréico no Leite). $O$ alto nível de NUL no rebanho significa a ineficiência de aproveitamento proteico, levando a uma grande excreção de nitrogênio uréico no leite e na urina, já os baixos índices podem tanto indicar um bom aproveitamento da proteína ou uma deficiência proteica na dieta. Os níveis indicados pela literatura como ideais para NUL vão de 10 a 16 mg/DI (ROSOLEM, 2013).

A ureia, utilizada como adulterante no leite, tem por princípio mascarar a adição de água tentando equiparar os parâmetros de identidade e qualidade do leite em termos de nível proteico (ANVISA, 2013). Consonante a Oga (2008), compostos à base de amônia $\left(\mathrm{NH}_{3}\right)$, como a ureia, liberam o gás amônia que, se inalado, ocasiona irritações nas vias aéreas superiores, pneumonite química e, em casos mais severos, edema agudo de pulmão, além de que, ao entrar em contato com a pele pode ocasionar queimaduras intensas ou dermatite de contato. Ainda de acordo com a autora, a absorção de grandes doses, em casos mais raros, pode levar à hipotonia, convulsões e coma, já a ingestão pode provocar necrose de liquefação, dor intensa na boca, garganta, região retroesternal e estômago entre outras consequências similares à ingestão de álcalis. 


\subsubsection{Formol}

O formaldeído, gás produzido a base de metanol, que em sua forma líquida, misturado à água e ao álcool, denomina-se formalina ou formol e apresenta entre 37 e 50\% de formaldeído acrescido de 6 a 15\% de álcool, que nesse caso atua como estabilizante (INCA, 2018). O formaldeído puro não é comercializado, visto que apresenta uma forte tendência à polimerização, para inibi-la, frequentemente, adiciona-se metanol à solução de formaldeído para viabilizar seu uso em diversos processos (KIMURA; CARVALHO, 2010).

O formol é utilizado na indústria cosmética, como componente de alisantes de cabelos; em hospitais, laboratórios de anatomia, na preservação de cadáveres; na indústria de madeira e papel; na de móveis, construção civil e têxtil. Também, pode ser utilizado como agente bacterisotático em alimentos específicos em alguns países (IARC, 2018).

A ingestão do formol, em geral a $35 \%$ pode ocasionar vômitos sanguinolentos, dores abdominais, disfagia, diarreia, sialorreia, além de distúrbios metabólicos e lesões renais, quando da sua conversão em ácido fórmico tem-se acidose metabólica, que em casos severos pode levar ao coma, hipotensão arterial, bem como insuficiência renal aguda (OGA, 2008). Na Tabela 3 , pode-se observar as consequências da exposição humana a diferentes concentrações de formol.

Segundo a ANVISA (2013), a ingestão de formol puro pode ocasionar dor intensa na boca e faringe, além de sintomas como acidose, hematemesis, anúria, proteinúria, vertigem, diarreia, dores abdominais com náuseas, vômitos, perda de consciência, coma e pode até levar à morte por falência respiratória. Muitas outras consequências podem ser advindas da sua ingestão como danos degenerativos no fígado, rins, coração e cérebro, está associado a câncer de nasofaringe, nasossinusal e há fortes evidências de estar associado à leucemia. 
Tabela 3. Consequências da exposição humana ao formol em determinadas concentrações.

\begin{tabular}{|c|c|c|}
\hline $\begin{array}{c}\text { Média de } \\
\text { concentração }\end{array}$ & Tempo médio & Efeitos à saúde população geral \\
\hline 0,8 - 1 ppm & Exposições repetidas & percepção olfativa \\
\hline até 2 ppm & Única ou repetida exposição & $\begin{array}{c}\text { irritante aos olhos, nariz e } \\
\text { garganta }\end{array}$ \\
\hline $3-5$ ppm & 30 minutos & $\begin{array}{c}\text { lacrimação e intolerância por } \\
\text { algumas pessoas }\end{array}$ \\
\hline $10-20$ ppm & Tempo não especificado & $\begin{array}{l}\text { dificuldade na respiração e forte } \\
\text { lacrimação }\end{array}$ \\
\hline $25-50$ ppm & Tempo não especificado & $\begin{array}{l}\text { edema pulmonar, pneumonia, } \\
\text { perigo de vida }\end{array}$ \\
\hline $50-100$ ppm & Tempo não especificado & pode causar a morte \\
\hline
\end{tabular}
Fonte: Adaptado de Inca, 2018.

\subsubsection{Peróxido de Hidrogênio}

O peróxido de hidrogênio é um peróxido inorgânico que consiste em dois grupos hidroxi unidos por uma ligação covalente oxigênio-oxigênio. É encontrado como solução aquosa incolor, estabilizada com mais de $60 \%$ de peróxido de hidrogênio, seus vapores podem irritar os olhos e as mucosas. Sob exposição prolongada ao fogo ou calor, os recipientes podem se romper violentamente devido à decomposição. O peróxido de hidrogênio é comumente utilizado para branquear tecidos e polpa de madeira, na fabricação de produtos químicos e processamento de alimentos (NATIONAL CENTER FOR BIOTECHNOLOGY INFORMATION, 2019c).

O peróxido de Hidrogênio $\left(\mathrm{H}_{2} \mathrm{O}_{2}\right)$, popularmente conhecido como água oxigenada, é um líquido incolor, de aroma levemente picante, não inflamável (QUIMICA MARAGNO, 2018) que atua como agente antimicrobiano ou branqueador, pode ser utilizado em alimentos como coadjuvante de tecnologia e, quando adicionado ao leite, em geral entre 300 e $800 \mathrm{ppm}$, tem o intuito de reduzir o número de bactérias - no Brasil essa medida não é permitida - no entanto, as principais preocupações toxicológicas referem-se à formação de compostos tóxicos por sua decomposição e ao valor nutricional dos alimentos, visto que a ingestão de pequenas quantidades de peróxido não produzem efeitos toxicológicos por serem rapidamente decompostos pelas células intestinais (ANVISA, 2007a). 
Soluções a 3\% não costumam ser consideradas muito perigosas, desde que a quantidade ingerida seja pequena, em doses maiores (cerca de 6\%) a ingestão de peróxido pode causar lesões cáusticas nas mucosas bucais e faringe, sangramento de garganta e estômago, além de a produção de gás oxigênio, em sua decomposição, que poderia ocasionar danos graves devido à pressão física exercida pelo gás. A ingestão de soluções a altas concentrações já registrara casos de edema ou derrame cerebral (ISOLAB, 2001).

\section{Materiais e Métodos}

\subsection{Materiais}

Os materiais utilizados na pesquisa estão listados, conforme segue:

- Leite cru;

- Eletrodos: $\mathrm{pH}$, condutividade e temperatura para Arduino;

- Arduino;

- Display de led;

- Jumpers;

- Protoboards;

- Fonte de alimentação USB;

- Ureia Agrícola em pérolas (Nitrogênio Total $45 \%$ - H olanda - Viana \& Viana Ltda ME);

- Hidróxido de sódio em escamas (Soda Cáustica cristalizada em escamas - Indaiá - Mantovani Industria Química Ltda);

- Peróxido de hidrogênio 3\% (Água Oxigenada - Solução de peróxido de hidrogênio $3 \%$ - UNIPHAR);

- Solução preparada de Formaldeído 0,2\% (Formaldeído 37\% ECIBRAT puro);

- Água;

- pHmetro - mPA210 - MS Tecnopon Instrumentação Científica;

- Condutivímetro Tec - 4MP - Tecnal;

- Termômetro do pHmetro de bancada Tecnal;

- Balança semianalítica. 
Para a realização da pesquisa buscou-se utilizar leite cru de origem conhecida e de boa qualidade, contaminando-o intencionalmente e em quantidades pré-determinadas. O leite cru utilizado, de vacas holandesas sadias, foi doado pela prefeitura do campus da Faculdade de Zootecnia e Engenharia de Alimentos (FZEA/USP), o qual foi coletado em galões (corretamente higienizados) de 2 e/ou 4 litros, diretamente do tanque de armazenamento refrigerado, logo após ordenhado. Os galões foram armazenados em refrigerador convencional com temperatura entre 6 e $10^{\circ} \mathrm{C}$.

\subsection{Desenvolvimento e montagem do equipamento}

O sistema de identificação de fraude em leite foi composto por uma estrutura contendo um Arduino Uno, um sensor pH do tipo SEM 0161, um de temperatura do tipo termopar e um sensor de condutividade elétrica do GF Signet da série 2820. As Figuras de 4 a 7 mostram os equipamentos utilizados no sistema, bem como suas especificações.

Figura 4. Arduino Uno

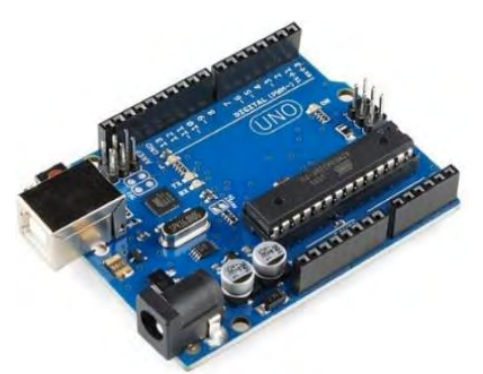

Fonte: http://www.filipeflop.com/categoria/arduino/

Figura 5. Sensor de $\mathrm{pH}$ do tipo SEM 0161

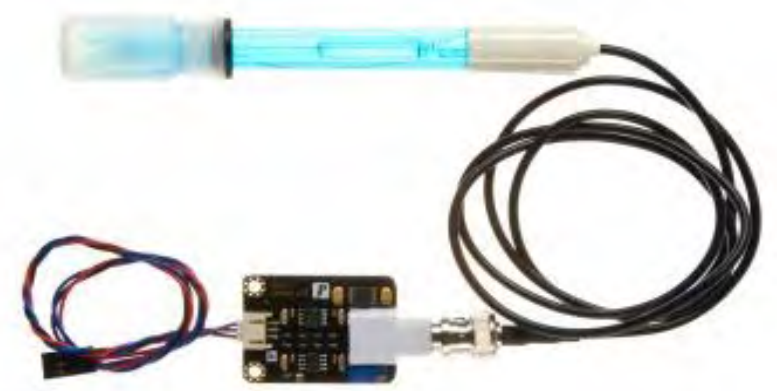

Fonte: https://www.dfrobot.com/wiki/index.php/PH_meter(SKU:_SEN0161) 
As especificações do sensor de $\mathrm{pH}$ são: Potência do módulo: $5.00 \mathrm{~V}$, Tamanho do módulo: $43 \mathrm{~mm} \times 32 \mathrm{~mm}$, Faixa de medição: 0-14PH, Temperatura de medição: $0-60^{\circ} \mathrm{C}$, Precisão: $\pm 0,1 \mathrm{pH}\left(25^{\circ} \mathrm{C}\right)$, Tempo de resposta: $\leq 1 \mathrm{~min}$, Sensor de pH com conector BNC, Interface PH2.0 (patch de 3 pés), Potenciômetro de ajuste de ganho, LED indicador de energia, Comprimento do cabo do sensor ao conector BNC: $660 \mathrm{~mm}$.

Figura 6. Sensor Termopar Tipo-K

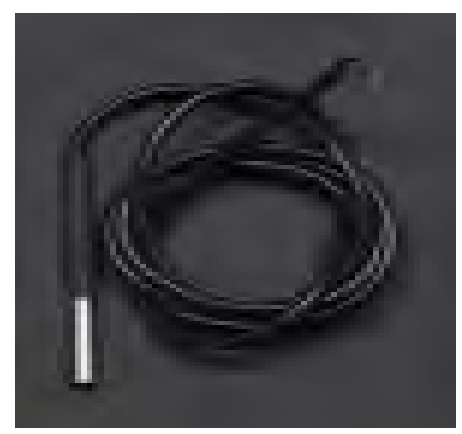

Fonte: Própria Autoria

As especificações técnicas do sensor Termopar Tipo-K estão descritas na Tabela 4.

Tabela 4. Especificações técnicas do Sensor de Temperatura Termopar Tipo-K

\begin{tabular}{c|ccccc} 
Sensor & $\begin{array}{c}\text { Faixa de } \\
\text { Medição }\end{array}$ & $\begin{array}{c}\text { Temperatura } \\
\text { de operação }\end{array}$ & $\begin{array}{c}\text { Precisão de } \\
\text { medição de } \\
\text { Temperatura }\end{array}$ & Termopar & Alimentação \\
\hline Termopar & $0-+600^{\circ} \mathrm{C}$ & $-20-85^{\circ} \mathrm{C}$ & $\pm 5^{\circ} \mathrm{C}$ & Tipo-K & $3-5$ VDC
\end{tabular}

Fonte: Adaptado de Sense Sensors \& Instruments (2015)

Figura 7. Sensor de Condutividade

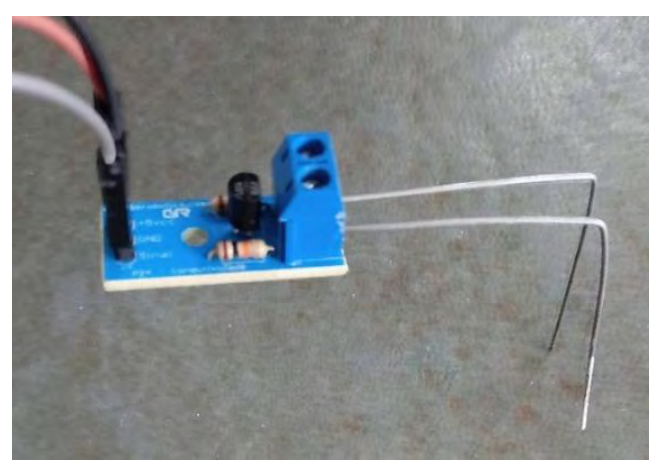

Fonte: Própria Autoria. 
O Arduino e os sensores de $\mathrm{pH}$, Condutividade e Temperatura foram ligados e integrados por meio de linguagem de programação Arduino e Protoboards, dando origem ao protótipo do equipamento, apresentado na Figuras 8.

Figura 8. Protótipo do sistema de identificação de fraude em leite: (a) Condutividade, (b) $\mathrm{pH}$ e (c) Temperatura.

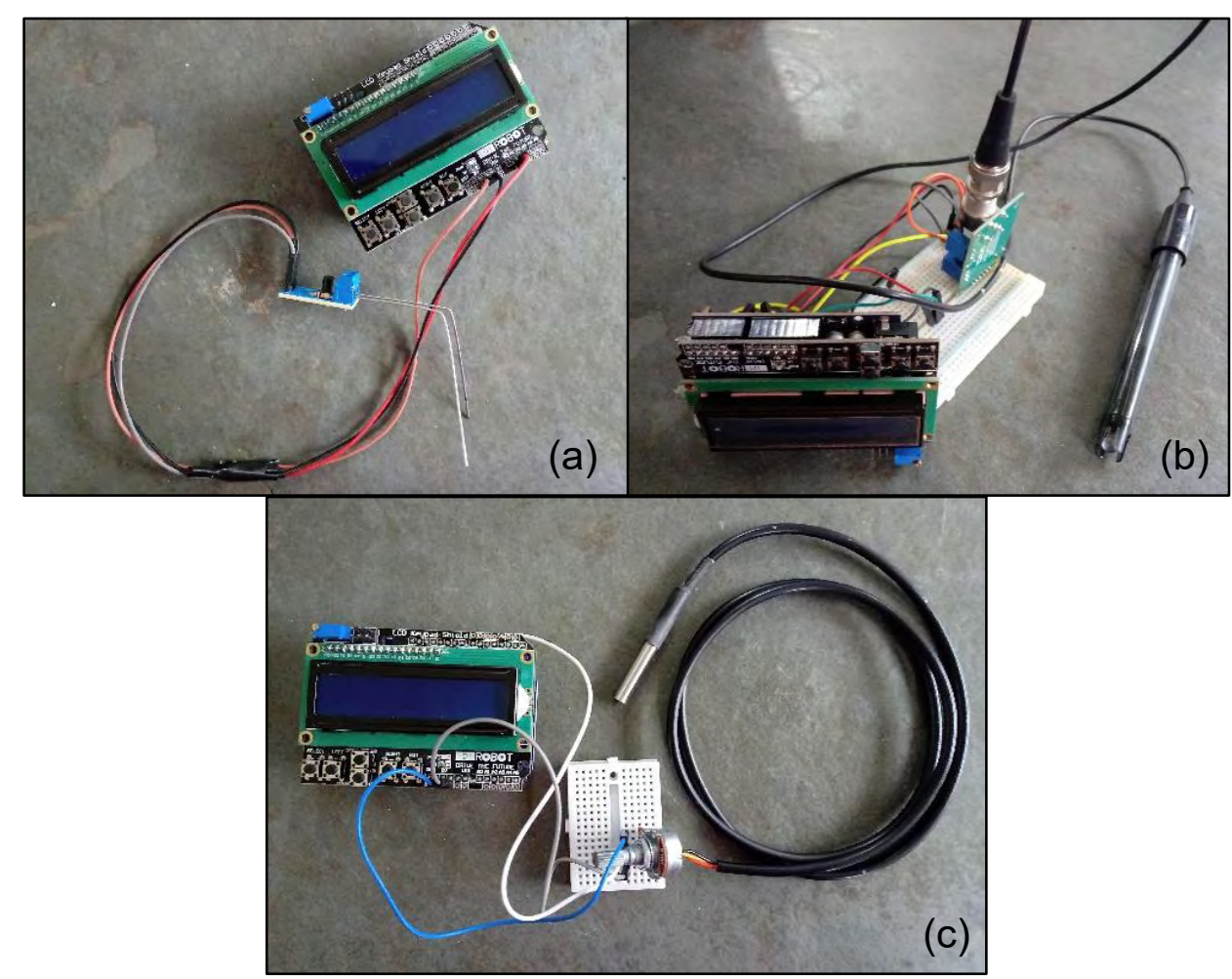

Fonte: Própria autoria.

\subsection{Análises físico-químicas do leite}

O RIISPOA (BRASIL, 2018) exige que o leite cru refrigerado cumpra uma série de requisitos físico-químicos, quais sejam: odor característico, liquido branco opalescente homogêneo, teores mínimos de gordura 3,0g/100g, de proteína total 2,9g/100g, lactose anidra 4,3g/100g, sólidos não-gordurosos de $8,4 \mathrm{~g} / 100 \mathrm{~g}$, sólidos totais $11,4 \mathrm{~g} / 100 \mathrm{~g}$, acidez titulável de 0,14 a $0,18 \mathrm{~g}$ ácido lático/100mL, densidade relativa a $15^{\circ} \mathrm{C}$ de 1,028 a 1,034 e índice crioscópico entre $-0,530^{\circ} \mathrm{H}$ e $-0,555^{\circ} \mathrm{H}$.

Essas análises físico-químicas obrigatórias listadas no RIISPOA (BRASIL, 2018) foram solicitadas à Prefeitura do Campus da Faculdade de Zootecnia e 
Engenharia de Alimentos (FZEA/ USP), devido à alta perecibilidade do leite e curto espaço de tempo para a realização das análises. Parte dos dados foram disponibilizados por meio de relatórios oriundos do setor de Grandes Animais da Divisão de Produção Agropecuária (DVAGRO) do campus, os demais não foram disponibilizados.

Os relatórios disponibilizados pela DVAGRO, setor de Grandes Animais, foram elaborados pelo Laboratório Da Associação Paranaense De Criadores Da Raça Holandesa - PARLPR que para suas análises de qualidade do leite utiliza técnicas baseadas em infravermelho para quantificar gordura, proteína, lactose e extrato seco total, já para análise de CCS (Contagem de Células Somáticas) utiliza técnica baseada em citometria de fluxo. Os métodos estão listados na Tabela 5.

Tabela 5. Metodologia de análise de qualidade do leite utilizada pela APCBRH.

\begin{tabular}{|c|c|c|c|}
\hline $\begin{array}{c}\text { Determinação ou } \\
\text { Ensaio }\end{array}$ & Técnica & $\begin{array}{l}\begin{array}{c}\text { Procedimento/ } \\
\text { Revisão }\end{array} \\
\end{array}$ & $\begin{array}{l}\text { Referência Bibliográfica do } \\
\text { Método }\end{array}$ \\
\hline $\begin{array}{l}\text { Determinação de } \\
\text { Gordura }\end{array}$ & \multirow{4}{*}{$\begin{array}{l}\text { Infraver- } \\
\text { melho }\end{array}$} & \multirow{4}{*}{$\begin{array}{c}\text { MPO - 07; 08; 09; } \\
10 ; 11 ; 12 / 02- \\
2008\end{array}$} & \multirow{4}{*}{$\begin{array}{l}\text { International Dairy Federation } \\
\text { (IDF) 141C - Determination of } \\
\text { milkfat, protein and lactose } \\
\text { content - Guidance on the } \\
\text { operation of mid-infrared } \\
\text { instruments. Brussels, Belgium, } \\
2000.15 \mathrm{p} \text {. }\end{array}$} \\
\hline $\begin{array}{l}\text { Determinação de } \\
\text { Proteína }\end{array}$ & & & \\
\hline $\begin{array}{l}\text { Determinação de } \\
\text { Lactose }\end{array}$ & & & \\
\hline $\begin{array}{l}\text { Determinação de } \\
\text { Extrato Seco Total }\end{array}$ & & & \\
\hline $\begin{array}{l}\text { Contagem de } \\
\text { Células Somáticas } \\
\text { (CCS) }\end{array}$ & $\begin{array}{l}\text { Citome- } \\
\text { tria de } \\
\text { Fluxo }\end{array}$ & $\begin{array}{c}\text { MPO - 07; 08; 09; } \\
\text { 10; 11; } 12 / 02- \\
2008\end{array}$ & $\begin{array}{l}\text { ISO 13366-2/International Dairy } \\
\text { Federation (IDF) 148-2 - Milk } \\
\text { Enumeration of somatic cells - } \\
\text { Part 2: Guidance on the } \\
\text { operation of fluoro-opto- } \\
\text { electronic counters. Brussels, } \\
\text { Belgium, 2006. } 15 p\end{array}$ \\
\hline
\end{tabular}

Os resultados das análises físico-químicas do leite fornecido pela prefeitura do campus da Faculdade de Zootecnia e Engenharia de Alimentos, pelo Programa de Análise de Rebanhos Leiteiros do Paraná da APCBRH (Associação Paranaense de Criadores de Bovinos da Raça Holandesa), estão apresentados na Tabela 6. Os resultados apresentados são referentes aos meses de junho e julho de 2019, meses em que os testes foram realizados, predominantemente. Os demais resultados não foram fornecidos pela Prefeitura 
do Campus justificado por sua indisponibilidade em seu banco de dados, como citado na Metodologia.

Na Tabela 6 é possível observar os teores de gordura, proteína, lactose, sólidos totais e CCS (contagem de células somáticas) referentes ao período do mês atual, aos últimos 12 meses, a média regional e estadual.

Tabela 6. Resultados das Análises de Qualidade do Leite.

\begin{tabular}{ccccccccc}
\hline \multicolumn{1}{c}{ jun/19 } \\
\hline $\begin{array}{c}\text { Descrição } \\
\text { Índices }\end{array}$ & $\begin{array}{c}\text { Controle } \\
\text { Atual }\end{array}$ & $\begin{array}{c}\text { Últimos } \\
\mathbf{1 2} \text { meses }\end{array}$ & $\begin{array}{c}\text { Média } \\
\text { Região }\end{array}$ & $\begin{array}{c}\text { Média } \\
\text { Estado }\end{array}$ & $\begin{array}{c}\text { Controle } \\
\text { Atual }\end{array}$ & $\begin{array}{c}\text { Últimos } \\
\mathbf{1 2} \text { meses }\end{array}$ & $\begin{array}{c}\text { Média } \\
\text { Região }\end{array}$ & $\begin{array}{c}\text { Média } \\
\text { Estado }\end{array}$ \\
\hline \% Gordura & 4,78 & 4,15 & 3,72 & 3,76 & 4,89 & 4,25 & 3,92 & 3,86 \\
$\%$ Proteína & 3,1 & 3,25 & 3,12 & 3,22 & 3,07 & 3,23 & 3,16 & 3,26 \\
$\%$ Lactose & 4,54 & 4,46 & 4,43 & 4,61 & 4,61 & 4,48 & 4,44 & 4,55 \\
$\%$ Sólidos & 13,36 & 12,78 & 11,96 & 12,58 & 13,52 & 12,89 & 12,15 & 12,63 \\
$\begin{array}{c}\text { CCS }(x \\
\text { 1000/ml) }\end{array}$ & 176 & 219 & 702 & 370 & 529 & 244 & 673 & 548 \\
\hline
\end{tabular}

Fonte: Adaptado de Relatório Sumário do Rebanho da APCGH/ APCBRH, 2019.

Segundo dados do próprio relatório, espera-se que os dias em leite sejam menores do que 180 dias, que o teor de gordura seja maior que $3,5 \%$ e o de proteína, maior que 3,2\%, bem como que o índice de CCS seja inferior a 283 (x 1000/ml). O controle atual de ambos os meses atende a exigência de dias em leite, tem teor de proteína próximo ao ideal e teor de gordura dentro do ideal e superior à média regional e estadual em ambos os casos.

Em junho o índice de CCS atende à exigência, mas no mês de julho é um pouco mais alta, provavelmente devido a uma contaminação do leite do rebanho com o leite produzido pelos animais 142, 143, 128, 181 e 68, que apresentaram teores de CCS muito acima do esperado: 381, 411, 9801, 583 e 1824, respectivamente.

A Instrução Normativa № 76 (BRASIL, 2018) exige que o teor mínimo de gordura seja de 3,0g/100g, mínimo de proteína total de 2,99g/100g, mínimo de lactose de 4,3g/100g e mínimo de sólidos totais de $11,4 \mathrm{~g} / 100 \mathrm{~g}$, de tal forma, o leite utilizado atendia a todas essas exigências da legislação brasileira. 


\subsection{Obtenção das soluções}

Um lote de leite íntegro ( $16 \mathrm{~L}$ ) fora subdividido em 4 lotes, dos quais um se adicionou hidróxido de sódio, a outro, peróxido de hidrogênio, ao terceiro formaldeído e, ao último, ureia e água, em concentrações conhecidas e condições controladas. Considerou-se o leite como azedo cerca de 2 dias após a coleta, quando do início da formação de coágulos, alteração de odor e acidificação dele. Todos os procedimentos foram realizados para o leite integral e para o leite azedo separadamente.

A um balão volumétrico de $100 \mathrm{~mL}$ adicionou-se $1,00 \mathrm{~g}$ ou $1,00 \mathrm{~mL}$ de um dos adulterantes, em seguida o seu volume foi preenchido com leite cru puro, ou seja, o leite coletado sem adição de nenhum adulterante, e homogeneizou-se o conteúdo, produzindo uma solução a $1,0 \%$ de concentração ( $\mathrm{m} / \mathrm{v}$ ou v/v). Na sequência foram pipetadas quantidades específicas da solução a 1,0\% para balões volumétricos de $50 \mathrm{~mL}$ e, como feito anteriormente, seu volume fora preenchido com leite cru puro, também homogeneizando-se o conteúdo e produzindo-se as soluções que seriam analisadas. Essas soluções foram transferidas a béqueres de $80 \mathrm{~mL}$ para se procederem as análises. Um volume de $50 \mathrm{~mL}$ de leite cru puro também foi adicionado a um béquer de $80 \mathrm{~mL}$ para análise, tendo este sido tratado como $0,0 \%$ ou branco. A Figura 9 descreve esse procedimento. Os tópicos do capítulo descrevem especificamente as soluções elaboradas para cada adulterante.

Figura 9. Produção de Soluções para análise.

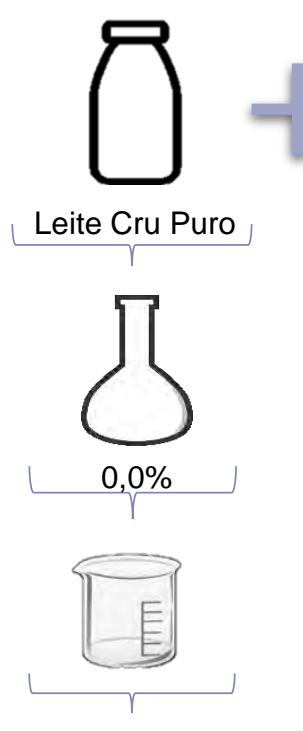

$0,0 \%$ ou Branco

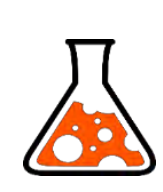

Adulterante

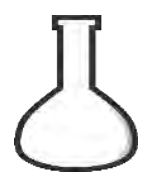

Concentrado $1,0 \%$
Leite Cru Puro
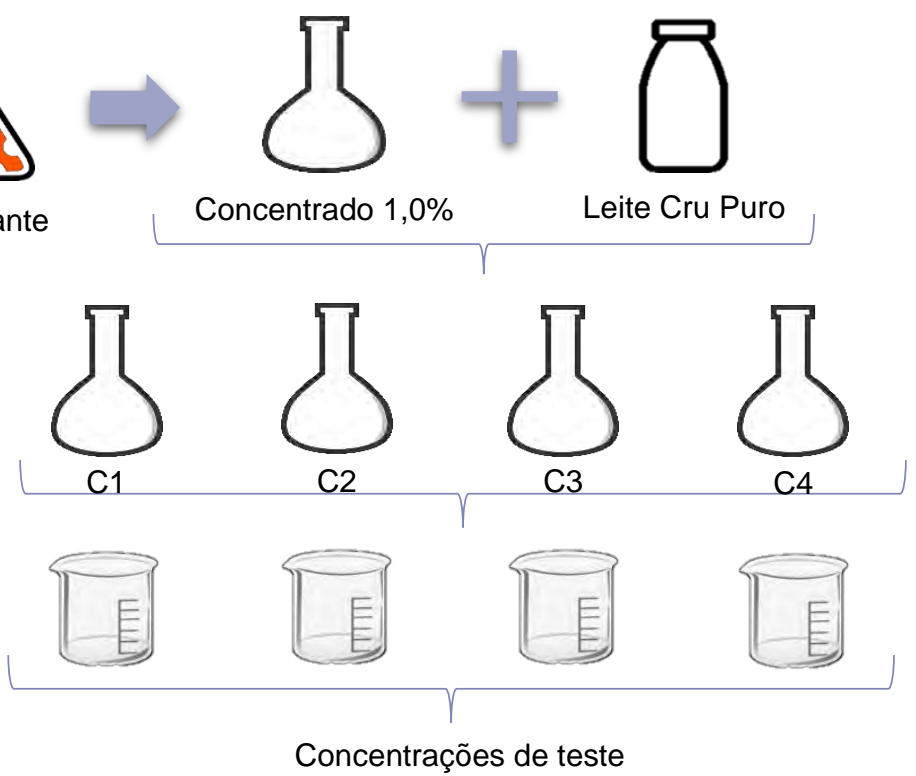

Concentrações de teste

Fonte: Própria Autoria. 


\subsubsection{Hidróxido de Sódio}

Pesou-se $1 \mathrm{~g}$ de hidróxido de sódio sobre papel não-absorvente, que foi transferido para um balão volumétrico de $100 \mathrm{~mL}$, completando-se o volume com leite puro e homogeneizado, obtendo-se uma solução de concentração 1,0\% $(\mathrm{m} / \mathrm{v})$. Em seguida, foram pipetados aos balões de $50 \mathrm{~mL}$ as alíquotas de $0,5 \mathrm{~mL}$, $1,25 \mathrm{~mL}$ e $2,5 \mathrm{~mL}$ da solução inicial, completando-se o volume com leite puro, perfazendo as concentrações de $0,01 \%$ 0,03\% e 0,05\% (m/v), respectivamente. Os seus conteúdos foram homogeneizados e transferidos a béqueres de $80 \mathrm{~mL}$. A um béquer limpo e vazio foi adicionado leite puro para ser utilizado como branco, no trabalho utilizado como $0,0 \%$.

\subsubsection{Peróxido de Hidrogênio}

Para o peróxido de hidrogênio $3 \%, 1 \mathrm{~mL}$ deste foi pipetado para um balão volumétrico de $100 \mathrm{~mL}$, completando-se o volume com leite puro e homogeneizando-o, obtendo-se uma solução de concentração 1,0\% (v/v). Na sequência, para os balões de $50 \mathrm{~mL}$ pipetaram-se as alíquotas de $2,5 \mathrm{~mL}, 5 \mathrm{~mL}$, $12,5 \mathrm{~mL}$ e $25 \mathrm{~mL}$ da solução inicial, completando-se o volume com leite puro, perfazendo as concentrações de $0,05 \%, 0,1 \%, 0,25 \%$ e $0,5 \%(\mathrm{v} / \mathrm{v})$, e com concentrações reais de $15 \mathrm{ppm}, 30 \mathrm{ppm}, 75 \mathrm{ppm}$ e $150 \mathrm{ppm}$, respectivamente. A exemplo do realizado com o hidróxido, seus conteúdos foram homogeneizados e transferidos a béqueres de $80 \mathrm{~mL}$, bem como a um béquer limpo e vazio foi adicionado leite puro para ser utilizado como branco, no trabalho denominado como $0,0 \%$.

\subsubsection{Formaldeído}

$1 \mathrm{~mL}$ de formaldeído $0,2 \%$ foi pipetado para um balão volumétrico de $100 \mathrm{~mL}$, completando-se o volume com leite puro e homogeneizando-o, obtendose uma solução de concentração $1,0 \%(\mathrm{v} / \mathrm{v})$. Na sequência, para os balões de $50 \mathrm{~mL}$ pipetaram-se as alíquotas de $0,5 \mathrm{~mL}, 2,5 \mathrm{~mL}, 5 \mathrm{~mL}$ e $25 \mathrm{~mL}$ da solução inicial, completando-se o volume com leite puro, perfazendo as concentrações de $0,01 \%, 0,05 \%, 0,1 \%$ e $0,5 \%(\mathrm{v} / \mathrm{v})$, respectivamente. As concentrações reais de formol nas amostras foram, respectivamente, 0,2ppm, 1,0ppm, 2,0ppm e 10,0ppm. Assim como os demais, os conteúdos dos balões foram homogeneizados e transferidos a béqueres de $80 \mathrm{~mL}$, bem como a um béquer 
limpo e vazio foi adicionado leite puro para ser utilizado como branco, no trabalho denominado como $0,0 \%$.

\subsubsection{Ureia e Água}

Pesou-se 1,0 g de ureia em papel não absorvente, a qual foi transferida para um balão volumétrico de $100 \mathrm{~mL}$, que foi preenchido com leite puro e homogeneizado, produzindo-se, desta forma, uma solução de concentração $1,0 \%(\mathrm{~m} / \mathrm{v})$. Para balões de $50 \mathrm{~mL}$, pipetaram-se $2,5 \mathrm{~mL}, 7,5 \mathrm{~mL}, 12,5 \mathrm{~mL}$ e $25 \mathrm{~mL}$ da solução inicial, perfazendo $0,05 \%, 0,15 \%, 0,25 \%$ e $0,5 \%(\mathrm{~m} / \mathrm{v})$, os quais se completaram com leite puro para a concentração de $0 \%$ de água. Para a concentração de $5 \%$ de água foram pipetados $2,5 \mathrm{~mL}$ dela aos balões de $50 \mathrm{~mL}$, $5 \mathrm{~mL}$ para a concentração de $10 \%$ de água e $7,5 \mathrm{~mL}$ para a de $15 \%$.

Cada balão foi homogeneizado e seu conteúdo transferido a um béquer de $80 \mathrm{~mL}$ e, as amostras de concentração $0,0 \%$ de ambos os aditivos, ou seja, o branco, o leite puro foi adicionado diretamente ao béquer de $80 \mathrm{~mL}$.

As concentrações de $0,0 \%$ representam o branco em relação ao respectivo aditivo, ureia ou água ou ambos. Todas as análises foram realizadas em duplicata, devido à vida útil do leite integro e do tempo demandado para a realização de tamanho número de análises. As concentrações de cada solução estão apresentadas no Quadro 1, onde cada linha apresenta a concentração utilizada de água e cada coluna representa a concentração de ureia, de tal forma a combinação cada linha e cada coluna do Quadro 1 foram chamadas de Tratamentos. Por exemplo, na segunda linha e quarta coluna, as concentrações eram de $5,0 \%$ de água e $0,25 \%$ de ureia.

Quadro 1. Concentrações das soluções Ureia vs. Água.

\begin{tabular}{|c|c|c|c|c|c|c|}
\hline \multicolumn{2}{|c|}{} & \multicolumn{5}{|c|}{ Ureia } \\
\cline { 3 - 7 } \multicolumn{2}{|c|}{} & $\mathbf{0 , 0 0 \%}$ & $\mathbf{0 , 0 5} \%$ & $\mathbf{0 , 1 5} \%$ & $\mathbf{0 , 2 5 \%}$ & $\mathbf{0 , 5 0} \%$ \\
\hline \multirow{4}{*}{ Água } & $\mathbf{0 , 0 0 \%}$ & $0 \% / 0 \%$ & $0 \% / 0,05 \%$ & $0 \% / 0,15 \%$ & $0 \% / 0,25 \%$ & $0 \% / 0,5 \%$ \\
\cline { 2 - 7 } & $\mathbf{5 , 0 0 \%}$ & $5 \% / 0 \%$ & $5 \% / 0,05 \%$ & $5 \% / 0,15 \%$ & $5 \% / 0,25 \%$ & $5 \% / 0,5 \%$ \\
\cline { 2 - 7 } & $\mathbf{1 0 , 0 0 \%}$ & $10 \% / 0 \%$ & $10 \% / 0,05 \%$ & $10 \% / 0,15 \%$ & $10 \% / 0,25 \%$ & $10 \% / 0,5 \%$ \\
\cline { 2 - 7 } & $\mathbf{1 5 , 0 0 \%}$ & $15 \% / 0 \%$ & $15 \% / 0,05 \%$ & $15 \% / 0,15 \%$ & $15 \% / 0,25 \%$ & $15 \% / 0,5 \%$ \\
\hline
\end{tabular}

Fonte: Própria Autoria. 


\subsection{Obtenção das Medidas}

As pontas de prova dos equipamentos padrões foram inseridas no béquer de concentração $0,0 \%$, tido como branco, obtendo-se uma leitura no equipamento, que fora anotada e o procedimento repetido por três vezes para cada béquer. Em seguida, o mesmo ensaio foi realizado para cada uma das demais concentrações, em ordem crescente, higienizando-se sempre todos os eletrodos com água destilada e secando com toalha de papel macia.

O procedimento foi repetido para o equipamento que está sendo desenvolvido. Para o hidróxido, o peróxido e o formaldeído o ensaio foi realizado em triplicata em ambos testes (Controle - equipamentos padrão; Protótipo equipamento em desenvolvimento). Para a interação ureia e água o ensaio foi realizado em duplicata, devido à vida útil do leite, bem como ao prazo para realização dos experimentos.

Todas as amostras tiveram sua condutividade, $\mathrm{pH}$ e temperatura medidas pelos equipamentos laboratoriais tradicionais e, em seguida, pelos sensores $(\mathrm{pH}$, condutividade e temperatura) programados pela equipe do LTSI (Laboratório de Tecnologia e Sistemas de Informação) na plataforma Arduino comparando os resultados entre si (Figura 10).

Figura 10. Experimento montado.

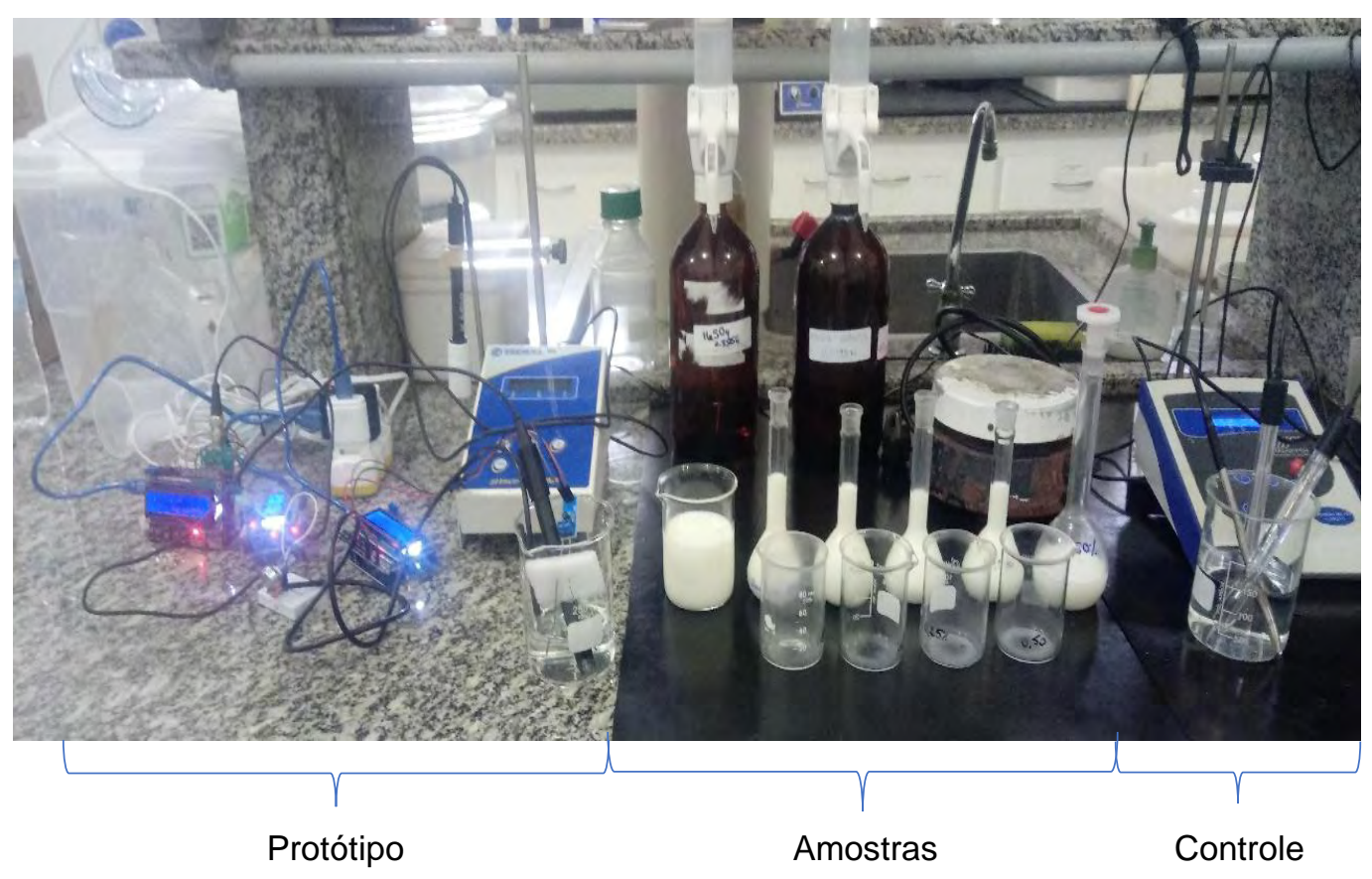

Fonte: Própria Autoria. 
Na Figura 10 pode-se observar o experimento montado como um todo, à esquerda o protótipo do equipamento montado em Arduino (Protótipo), ao centro as soluções preparadas para análise e, finalmente à direita, os equipamentos padrões (Controle).

O experimento foi conduzido no Laboratório de Tecnologia Ambiental do Departamento de Engenharia de Alimentos da Universidade de São Paulo, campus de Pirassununga no período de março a julho de 2019. Entre março e abril foram realizados testes de funcionamento do sistema, bem como testes preliminares semelhantes aos conduzidos apenas com o intuito de fazer com que o equipamento estivesse apropriado ao uso durante os testes do mesmo.

\subsection{Análise estatística}

Os resultados obtidos foram tabulados no Microsoft Office Excel® 2016, nas análises estatísticas consideraram-se as informações contidas no intervalo da média \pm três desvios-padrão de cada variável.

Análise de regressão linear múltipla com efeitos fixos foi realizada para avaliar a concentração percentual dos adulterantes em estudo (hidróxido de sódio, peróxido de hidrogênio, ureia e formol), sobre as variáveis temperatura $\left({ }^{\circ} \mathrm{C}\right), \mathrm{pH}$ e condutividade $(\mathrm{mS} / \mathrm{cm})$ considerando no modelo de análise como efeitos fixos, o equipamento utilizado (Controle - Equipamentos de bancada e Protótipo - Protótipo desenvolvido), a Condição do leite (íntegro ou azedo), utilizando um nível de significância de 5\%.

Quando as concentrações apresentaram diferença significativa, para a comparação dos resultados obtidos entre as concentrações, foi utilizado o teste de Tukey. Também foram realizadas análises estatísticas descritivas, apresentadas nos Anexos A, B, C e D, para o hidróxido de sódio $(\mathrm{NaOH})$, peróxido de hidrogênio $\left(\mathrm{H}_{2} \mathrm{O}_{2}\right)$, formaldeído $\left(\mathrm{CH}_{2} \mathrm{OH}\right)$ e ureia $\left(\mathrm{CH}_{4} \mathrm{~N}_{2} \mathrm{O}\right)$, respectivamente. Todas as análises estatísticas foram realizadas no software SAS - Statistical Analysis System (Versão 9.3). 


\section{Resultados e Discussão}

5.

\subsection{Análise das características do leite puro e intencionalmente adulterado}

As análises das características físico-químicas do leite puro, ou seja, sem adição de adulterantes, e do leite adulterado intencionalmente se procederam. Os resultados das variáveis condutividade, temperatura e pH estão dispostos no capítulo separados por adulterante.

\subsubsection{Hidróxido de sódio}

\subsubsection{Condutividade}

A condutividade elétrica do leite é determinada pela concentração de íons, dos quais os de maior relevância são o sódio, o potássio e o cloreto (ZAFALON et al, 2005). A adição de hidróxido de sódio aumenta o teor de sódio do leite e, dessa forma, o esperado é se observar tal elevação proporcional à concentração adicionada.

As médias dos resultados das amostras de leite analisadas foram plotadas no gráfico 1, ele mostra o comportamento das mesmas comparando-se os equipamentos controle e protótipo, bem como as linhas de tendência dos resultados e suas respectivas equações. Pode-se observar que os comportamentos são bastante próximos e que os coeficientes de determinação são altos, superiores a 0,9. Mesmo com coeficientes altos, o controle teve um coeficiente de determinação ligeiramente mais baixo que o protótipo, o que é interessante, pois mostra que o protótipo é tão ou mais eficiente nessas medidas quanto o equipamento controle. 
Gráfico 1. Resposta média da condutividade do leite adicionado ou não de $\mathrm{NaOH}$ em função da concentração.

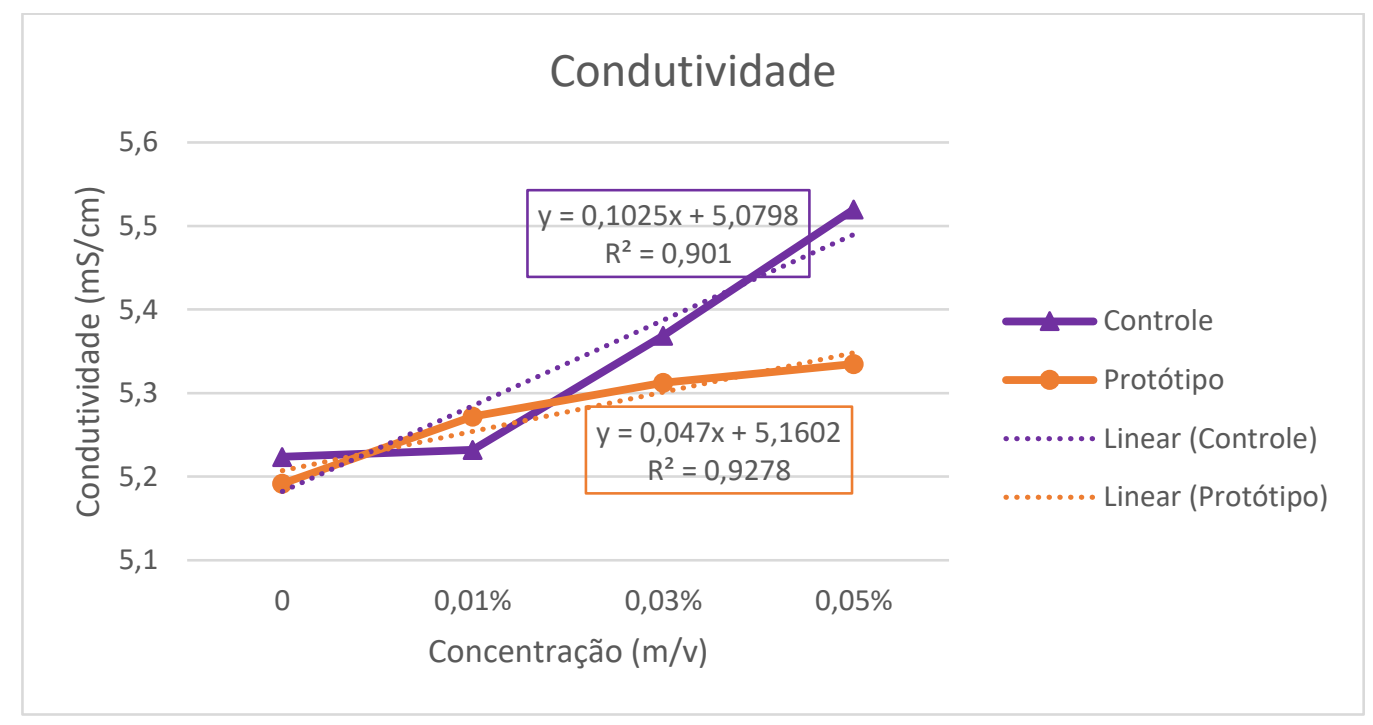

Para entender de maneira mais clara o comportamento das respostas foi feita uma análise global dos resultados, onde a condição do leite foi colocada como efeito fixo, bem como o equipamento e a concentração de adulterante. $\mathrm{Na}$ análise de efeitos fixos pode-se observar que tanto a concentração do adulterante quanto a condição do leite foram significativos, já o equipamento não foi um fator significativo. Este resultado era o almejado, pois demonstra que o equipamento controle e o protótipo não diferem entre si, bem como que a concentração de adulterante e a condição do leite afetam a resposta da condutividade, permitindo assim diferir os resultados. A equação 1 apresenta o modelo de regressão que relaciona esses efeitos significativos de maneira global.

$Y=5,29375-0,09026 x$ Condição $+4,22732 x$ Concentração $\quad R^{2}=0,5142$

Onde: $\mathrm{Y}=$ Medida de Condutividade $(\mathrm{mS} / \mathrm{cm}) ;$ Condição: Azedo $=1,0$ e Integro $=0,0$; Concentração de Hidróxido (\%).

A partir da equação proposta pode-se notar que o leite quando azedo apresenta condutividade menor do que o leite quando integro, pois o coeficiente negativo provoca uma redução do valor absoluto em cerca de 0,09 $\mathrm{mS} / \mathrm{cm}$. Já observando-se o coeficiente relacionado à concentração, pode-se notar que o aumento da concentração provoca a elevação do valor da condutividade como 
esperado, tanto pelo aumento da quantidade de sódio, quanto pela formação de sais.

Conforme esperado, a adição de hidróxido ao leite provocou o aumento da condutividade, devido ao aumento da concentração de sódio e sua consequente formação de sal, e as médias das respostas para cada concentração diferiram significativamente pelo teste de Tukey, o que pode ser observado na Tabela 7, onde letras maiúsculas iguais indicam que as médias por elas seguidas não diferem estatisticamente entre si, o que implica dizer que ambos os testes foram capazes de diferenciar as concentrações de hidróxido adicionadas ao leite.

Tabela 7. Médias da condutividade em relação à concentração de hidróxido de sódio intencionalmente adicionado ao leite.

\begin{tabular}{ccc}
\hline \multicolumn{1}{c}{ Concentração (\%) } & Cond. Média $(\mathbf{m S} / \mathbf{c m})$ & \\
\hline $\mathbf{0 , 0 0}$ & 5,2119 & $\mathrm{D}$ \\
$\mathbf{0 , 0 1}$ & 5,2608 & $\mathrm{C}$ \\
$\mathbf{0 , 0 3}$ & 5,3452 & $\mathrm{~B}$ \\
$\mathbf{0 , 0 5}$ & 5,4245 & $\mathrm{~A}$ \\
\hline uidas por letras maiúsculas iguais não diferem significativamente entre si.
\end{tabular}

*Médias seguidas por letras maiúsculas iguais não diferem significativamente entre si.

Da mesma forma, analisaram-se o leite azedo e íntegro isoladamente, as médias dos resultados obtidos para cada um foi plotada no Gráfico 2 junto às linhas de tendência respectivas e suas equações. No Gráfico 2 é possível notar que o comportamento da variação da condutividade do leite adicionado de hidróxido de sódio, estando ele íntegro ou azedo, é bastante próximo, entretanto entre as concentrações de 0,3 e 0,5\% o leite azedo sofre uma alteração mais intensa de condutividade do que o leite íntegro. O leite azedo também apresenta um coeficiente de determinação mais alto (superior a 0,97) frente ao leite íntegro $(0,94)$ o que pode estar relacionado com uma maior facilidade de identificar a adição de hidróxido a ele. 
Gráfico 2. Resposta da condutividade do leite azedo e do leite íntegro adicionado ou não de $\mathrm{NaOH}$ em função da concentração.

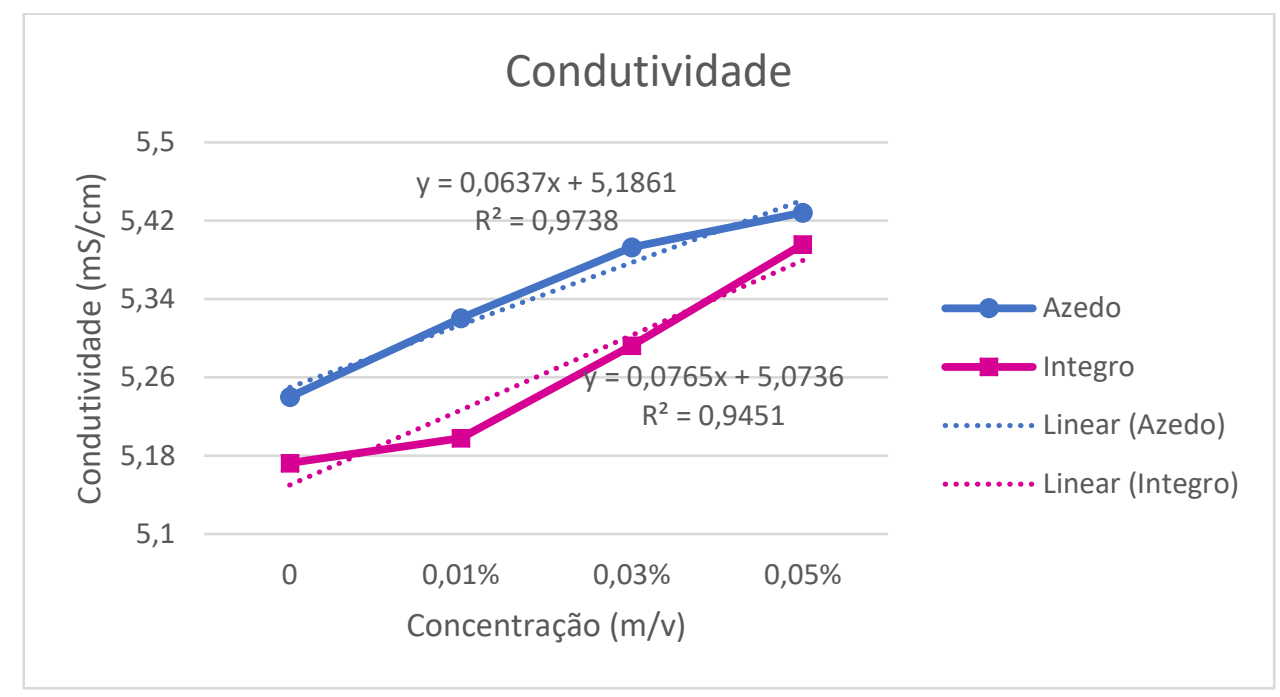

Pela análise estatística realizada o leite azedo apresentou como efeitos significativos o equipamento e a concentração de adulterante. A equação 2 apresenta o modelo de regressão obtido para o leite azedo, onde é possível observar que apesar de os equipamentos, nesse teste, apresentarem uma diferença significativa entre eles, a resposta é influenciada em cerca de 0,2 $\mathrm{mS} / \mathrm{cm}$. Já a concentração tem uma influência mais alta sobre a resposta da condutividade, com coeficiente em torno de $4,24 \mathrm{mS} / \mathrm{cm}$, sua elevação provoca um aumento imediato na condutividade, como esperado. O Gráfico 2 foi construído baseado na equação 2, como feito anteriormente no Gráfico 1 .

$Y=5,38691-0,21399 x E+4,24308 x$ Concentração $\quad R^{2}=0,7898$

Onde: $\mathrm{Y}=$ Medida de Condutividade $(\mathrm{mS} / \mathrm{cm})$ do leite Azedo; Concentração = Concentração de Hidróxido (\%); E = Equipamento: Controle = 0,0 e Protótipo = 1,0.

Para verificar a capacidade de diferenciar as respostas, foi feita análise de Tukey que revelou que os equipamentos foram capazes de distinguir todas as concentrações de hidróxido adicionadas, ela está apresentada na Tabela 8 e aponta que todas as concentrações diferem estatisticamente entre si, o que está representado pelas letras maiúsculas diferentes na tabela. 
Tabela 8. Médias da Condutividade em relação à Concentração de hidróxido de sódio intencionalmente adicionado ao leite azedo.

\begin{tabular}{ccl}
\hline Concentração (\%) & Cond. Média (mS/cm) & \\
\hline $\mathbf{0 , 0 0}$ & 5,2613 & $\mathrm{D}$ \\
$\mathbf{0 , 0 1}$ & 5,3419 & $\mathrm{C}$ \\
$\mathbf{0 , 0 3}$ & 5,4141 & $\mathrm{~B}$ \\
$\mathbf{0 , 0 5}$ & 5,4816 & $\mathrm{~A}$ \\
\hline
\end{tabular}

*Médias seguidas por letras maiúsculas iguais não diferem significativamente entre si.

Já em relação ao leite integro, os equipamentos não apresentaram diferença estatística significativa, apenas a Concentração apresentou. A equação 3 apresenta o modelo estimado para essa relação. Mesmo a concentração sendo significativa na análise, os equipamentos só foram capazes de diferenciar concentrações a partir de 0,03\% (m/v) e identificar a adulteração do leite, o que pode ser verificado na análise de Tukey apresentada na Tabela 9.

Onde: $\mathrm{Y}=$ Medida de Condutividade $(\mathrm{mS} / \mathrm{cm})$ do leite integro; Concentração = Concentração de Hidróxido (\%).

Tabela 9. Médias da Condutividade em relação à Concentração de hidróxido de sódio intencionalmente adicionado ao leite integro.

\begin{tabular}{ccc}
\hline Concentração (\%) & Cond. Média $(\mathbf{m S} / \mathbf{c m})$ & \\
\hline $\mathbf{0 , 0 0}$ & 5,1697 & $\mathrm{C}$ \\
$\mathbf{0 , 0 1}$ & 5,1981 & $\mathrm{C}$ \\
$\mathbf{0 , 0 3}$ & 5,2925 & $\mathrm{~B}$ \\
$\mathbf{0 , 0 5}$ & 5,3959 & $\mathrm{~A}$ \\
\hline
\end{tabular}

*Médias seguidas por letras maiúsculas iguais não diferem significativamente entre si.

A condutividade, observando-se as análises apresentadas, pode ser um bom indicador da adição de hidróxido de sódio ao leite, visto que o aumento de íons de sódio tende a aumentar a condutividade do leite, bem como a formação de sais também tem esse efeito. Ainda é possível inferir que a concentração e a condição do leite são os fatores de maior influência em todos os cenários analisados. 
O coeficiente de determinação $\left(R^{2}\right)$ estimado das equações propostas foi um pouco menor do que o esperado, mas pode ser melhorado otimizando-se 0 protótipo, tanto em termos de software quanto de hardware, o que reduziria os erros e melhoraria a repetibilidade do estudo, variando mais concentrações e, talvez, aumentando o número de repetições do estudo.

\subsubsection{Temperatura}

As médias das temperaturas obtidas nas análises foram plotadas no Gráfico 3. O comportamento das respostas foi semelhante e, pouco mais distante que os anteriores, provavelmente por conta de alguns ajustes que devem ser feitos no protótipo. O protótipo do sensor de temperatura também apresentou coeficiente de determinação mais alto que o controle, o que pode indicar ser conveniente seu uso.

Gráfico 3. Médias de Temperatura do leite adicionado ou não de $\mathrm{NaOH}$ em função da concentração.

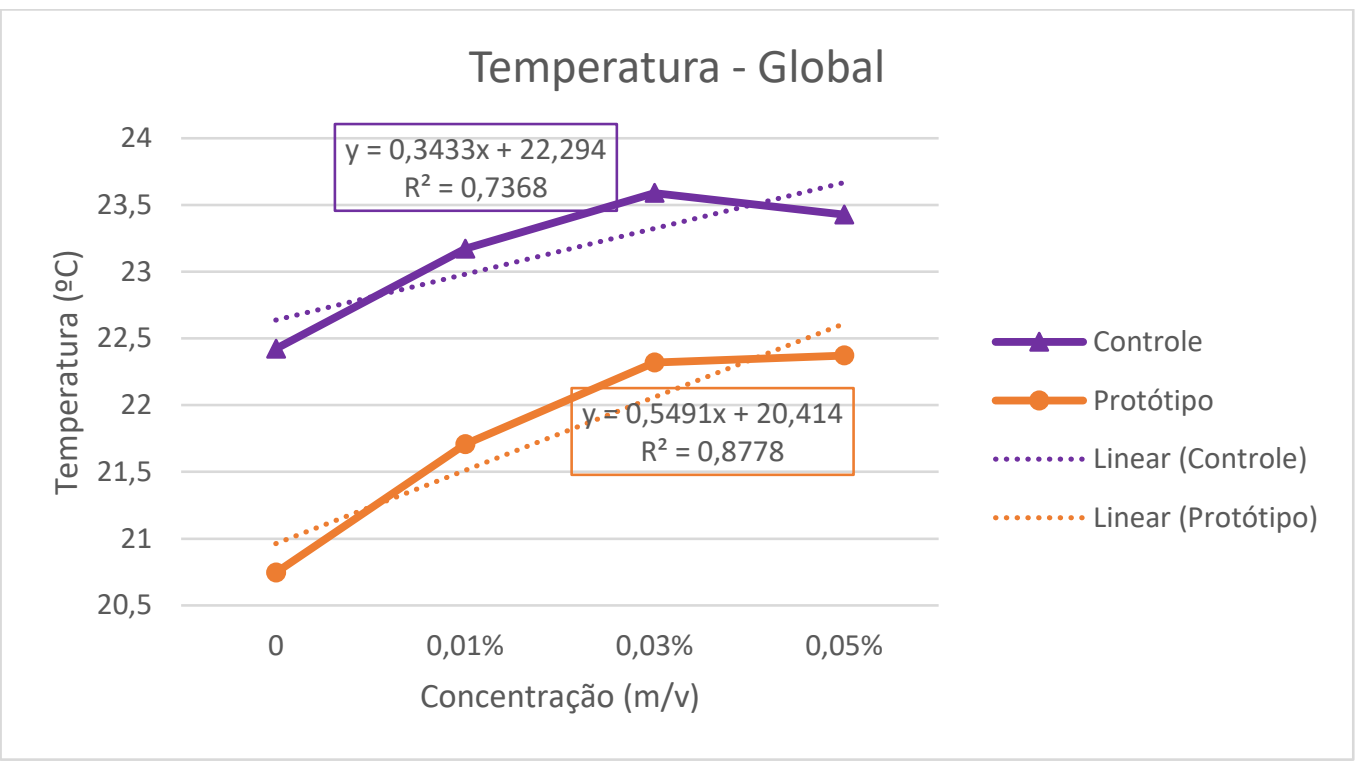

Em uma análise global dos parâmetros estudados em relação a temperatura do leite adicionado de hidróxido de sódio, verificou-se que a condição, o teste e a concentração foram significativos na avaliação, assim o modelo de regressão para essa análise está apresentado na eq. 4.

$$
\begin{array}{cc}
Y=21,32219 & -1,40077 x E+2,5230 x \text { Condição } \\
& +25,2923 x \text { Concentração }
\end{array} \quad R^{2}=0,6838
$$


Onde: $\mathrm{Y}=$ Medida de Temperatura $\left({ }^{\circ} \mathrm{C}\right)$; Condição: Azedo $=1,0$ e Integro $=0,0$; Concentração de Hidróxido (\%); $E$ = equipamento: Controle = 0,0 e Protótipo = 1,0.

A condição do leite pode provocar uma variação de temperatura de até $2,52^{\circ} \mathrm{C}$ adicionado de hidróxido, já o equipamento tem uma influência menor, cerca de $1,4^{\circ} \mathrm{C}$, mas o fator que apresenta maior impacto na resposta da temperatura é a concentração. A adição do hidróxido ao leite provoca uma reação exotérmica quando ele entra em contato com a água presente, aumentando a temperatura do leite, proporcionalmente à sua concentração. A diferença significativa entre as médias das respostas da temperatura pode ser observada na Tabela 10.

Tabela 10. Médias da Temperatura em relação à Concentração de hidróxido de sódio intencionalmente adicionado ao leite.

\begin{tabular}{ccc}
\hline Concentração $(\%)$ & Temp. Média $\left({ }^{\circ} \mathbf{C}\right)$ & \\
\hline $\mathbf{0 , 0 0}$ & 21,4801 & $\mathrm{C}$ \\
$\mathbf{0 , 0 1}$ & 22,4403 & $\mathrm{~B}$ \\
$\mathbf{0 , 0 3}$ & 22,9544 & $\mathrm{~A}$ \\
$\mathbf{0 , 0 5}$ & 22,8997 & $\mathrm{~A}$ \\
\hline seguidas por letras maiúsculas iguais não diferem significativamente entre si.
\end{tabular}

*Médias seguidas por letras maiúsculas iguais não diferem significativamente entre si.

A exemplo do que foi feito para a condutividade, também foi plotado um gráfico (Gráfico 4) com as temperaturas médias obtidas nas análises para a condição do leite e estimado o modelo para a temperatura com base na condição do leite. Observa-se no gráfico referido que o comportamento das respostas de ambas condições é semelhante, o que as diferencia, principalmente, é a grandeza da medida. Acredita-se que um ajuste de modelo no protótipo seja suficiente para tornar esse resultado mais preciso. Em relação ao modelo, para o leite azedo tanto o teste quanto a concentração foram significativas, este pode ser verificado na eq. 5 . 
Gráfico 4. Resposta da Temperatura do leite adicionado ou não de $\mathrm{NaOH}$ em função da concentração.

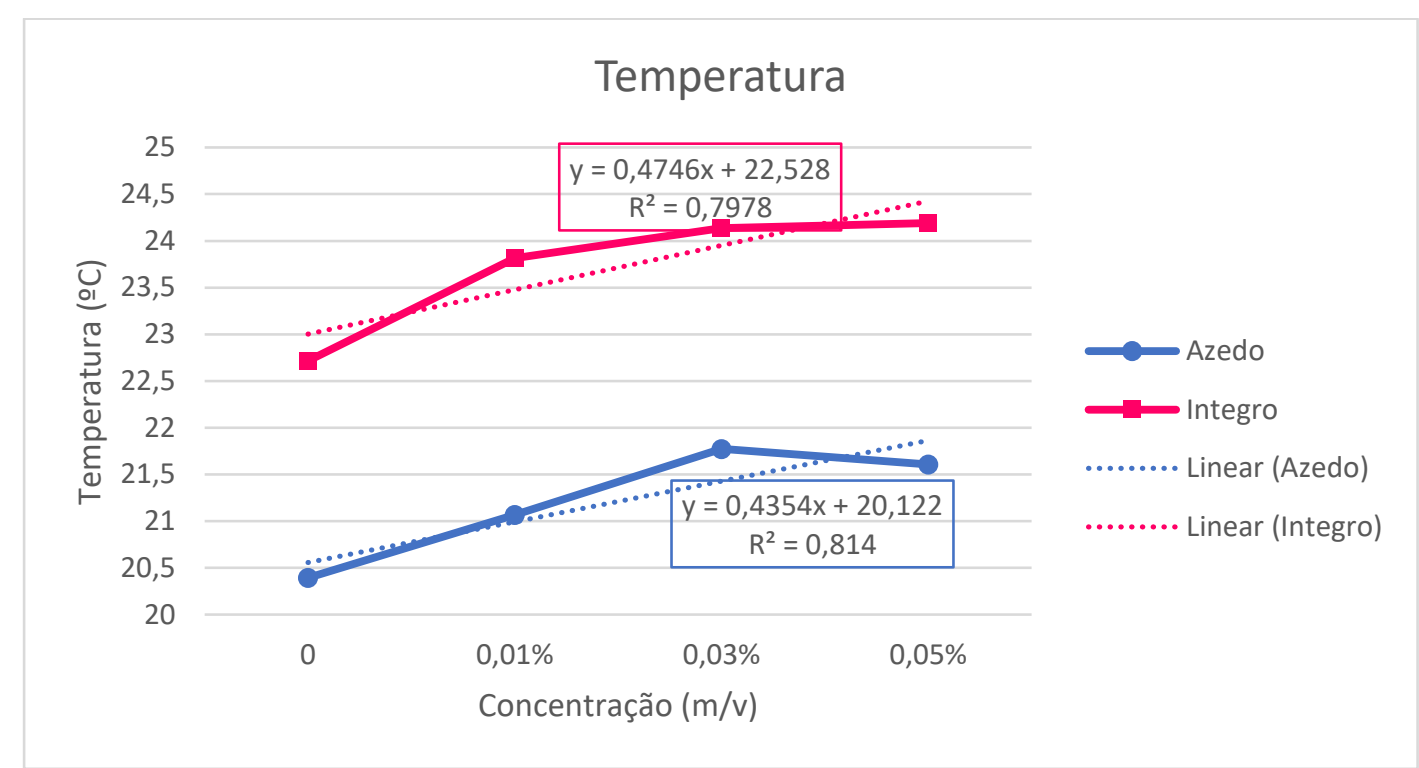

$Y=21,53267-1,86733 x$ Teste $+25,83201 x$ Concentração $\quad R^{2}=0,5602$

Onde: $\mathrm{Y}=$ Medida de Temperatura $\left({ }^{\circ} \mathrm{C}\right)$; Concentração de Hidróxido (\%); $\mathrm{E}=$ Equipamento: Controle $=0,0 ;$ Protótipo $=1,0$.

A concentração no modelo é o fator de maior influência na resposta da temperatura do leite, já o equipamento apresenta uma bem menor, de menos de $2^{\circ} \mathrm{C}$. Essa variação da temperatura frente o teste pode ser devido ao modelo do sensor utilizado no protótipo, por sua sensibilidade não ser tão alta quanto esperada. A comparação das médias da temperatura frente às concentrações adicionadas de $\mathrm{NaOH}$ pode ser observada na Tabela 11.

Tabela 11. Médias da Temperatura em relação à Concentração de hidróxido de sódio intencionalmente adicionado ao leite Azedo.

\begin{tabular}{ccc}
\hline Concentração (\%) & Temp. Média $\left({ }^{\circ} \mathbf{C}\right)$ & \\
\hline $\mathbf{0 , 0 0}$ & 20,2032 & $\mathrm{C}$ \\
$\mathbf{0 , 0 1}$ & 21,0661 & $\mathrm{~B}$ \\
$\mathbf{0 , 0 3}$ & 21,7739 & $\mathrm{~A}$ \\
$\mathbf{0 , 0 5}$ & 21,6089 & $\mathrm{AB}$ \\
\hline
\end{tabular}

*Médias seguidas por letras maiúsculas iguais não diferem significativamente entre si. 
Para o leite integro nenhum dos parâmetros (concentração e equipamento) foi significante na análise, para tanto, não foi elaborado o seu modelo de regressão. A ausência de significância estatística da concentração indica, no estudo, que a análise não foi eficiente para identificar a adição de hidróxido no leite. Já em relação ao equipamento indica que ambos os métodos não foram capazes de identificar a adição de hidróxido na análise.

\subsubsection{3. $\mathrm{pH}$}

Para o pH, aplicando a mesma metodologia, observou-se que os equipamentos não foram significativos, o que indica a semelhança entre os testes. A condição foi estatisticamente diferente, o que também é relevante, visto que as análises foram capazes de diferenciar o leite entre azedo e integro, mas as concentrações de hidróxido a ele adicionadas não foram significativas, indicando que o método não foi capaz de diferenciar o leite adulterado do não adulterado. De tal forma, o modelo não foi significativo.

\subsubsection{Peróxido de hidrogênio}

\subsubsection{Condutividade}

Analisando-se o leite sem distinguir integro de azedo, para a condutividade, o teste e a condição foram significativos, mas a concentração de peróxido de hidrogênio não foi, o que implica dizer que o método não foi capaz de identificar a presença de peróxido no leite e, dessa forma, o modelo não foi significativo. Os testes apesar de diferirem entre si estatisticamente não puderam identificar a presença de peróxido no leite.

Avaliando-se o leite azedo e o leite integro separadamente, o mesmo ocorreu em relação ao modelo global. Assim, o modelo de medida de condutividade não foi significativo em nenhuma das análises realizadas.

As concentrações analisadas são bastante baixas, sendo elas em relação à solução inicial 0,05\%, 0,1\%, 0,25\% e 0,5\% (v/v), e com concentrações reais de $15 p p m$, 30ppm, 75ppm e 150ppm. Para melhorar os resultados talvez seja 
adequado refazer o teste com concentrações mais altas de peróxido ou a substituição do sensor por um de maior sensibilidade.

\subsubsection{Temperatura}

Para a temperatura, o equipamento, a condição e a concentração foram significativas no modelo apresentado na eq. 6. O modelo serviu de base para o Gráfico 6, que elucida melhor os resultados obtidos na análise. Observando-se o modelo obtido podemos notar que o equipamento apresentou o mesmo comportamento do modelo para o hidróxido, ou seja, uma redução da temperatura da amostra próxima à $1,4^{\circ} \mathrm{C}$, o que provavelmente ocorreu por conta de ajustes no modelo programado no Protótipo.

$$
\begin{array}{rlrl}
Y=24,19188 & -1,36990 x E-0,51988 x \text { Condição } & \\
+1,74674 x \text { Concentração } & R^{2}=0,6941
\end{array}
$$

Onde: $\mathrm{Y}=$ Medida de Temperatura $\left({ }^{\circ} \mathrm{C}\right)$; Condição: Azedo $=1,0$ e Integro $=0,0$; Concentração de Peróxido (\%); E = Equipamento: Controle $=0,0$ e Protótipo = 1,0.

A concentração de peróxido faz com que aumente, em cerca de $1,75^{\circ} \mathrm{C}$, a temperatura da solução, o que é um valor bastante representativo quando se trata de alimentos perecíveis. Já a condição do leite tem um impacto um pouco menor, o leite azedo, no modelo, ocasiona uma redução de $0,52^{\circ} \mathrm{C}$ em relação à temperatura do leite íntegro. As médias da temperatura em relação à concentração de peróxido apresentam diferença significativa nesse modelo global, onde são considerados ambas condições do leite. A análise de Tukey, que demonstra essa diferença está apresentada na Tabela 12.

Tabela 12. Médias da temperatura em relação à concentração de peróxido de hidrogênio intencionalmente adicionado ao leite.

\begin{tabular}{ccc}
\hline Concentração (\%) & Temperatura Média $\left({ }^{\circ} \mathbf{C}\right)$ & \\
\hline $\mathbf{0 , 0 0}$ & 22,7096 & $\mathrm{D}$ \\
$\mathbf{0 , 0 5}$ & 23,5195 & $\mathrm{C}$ \\
$\mathbf{0 , 1 0}$ & 23,7283 & $\mathrm{BC}$ \\
$\mathbf{0 , 2 5}$ & 23,7631 & $\mathrm{~B}$ \\
$\mathbf{0 , 5 0}$ & 23,9948 & $\mathrm{~A}$ \\
\hline
\end{tabular}

*Médias seguidas por letras maiúsculas iguais não diferem significativamente entre si.

Apesar de as médias, em geral, diferirem significativamente entre si, o modelo não foi capaz de diferenciar as médias de temperatura entre as soluções 
de $0,05 \%$ e $0,1 \%$, nem entre $0,1 \%$ e $0,25 \%$, o que pode ser notado pela letra maiúscula que segue essas médias, pois quando são iguais significam não serem diferenciadas entre si.

As médias das temperaturas obtidas no experimento foram plotadas no Gráfico 5, relacionando a concentração e a condição do leite (azedo e íntegro), por ele é possível notar que o leite azedo apresenta um comportamento diferente dos anteriores, enquanto o leite integro apresenta um comportamento mais próximo dos anteriores e da linearidade.

Gráfico 5. Resposta da Temperatura do leite integro adicionado ou não de $\mathrm{NaOH}$ em função da concentração.

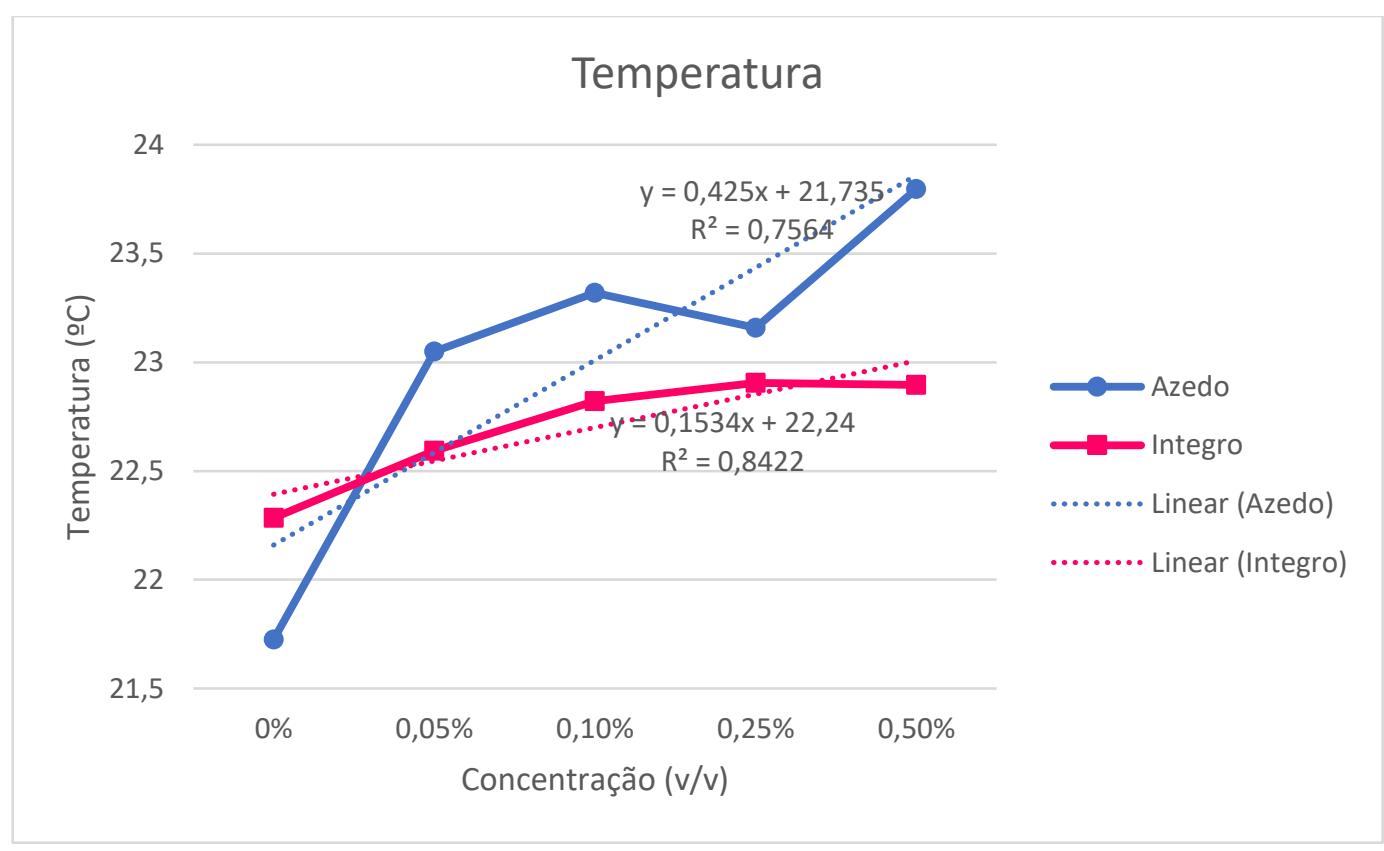

Para o leite azedo, tanto o teste quanto a concentração foram significativos estatisticamente, desta forma o modelo proposto se encontra na eq. 7. O equipamento foi significativo e afeta, na mesma proporção que os anteriores, o resultado da análise, o que reitera a proposição que provavelmente se deva a algum ajuste na programação do protótipo. Da mesma forma, a concentração de peróxido de hidrogênio na solução analisada foi o fator que afetou de forma mais significativa o modelo.

$$
Y=24,13257-1,49064 x E+2,38698 x \text { Concentração } \quad R^{2}=0,7144
$$


Onde: $\mathrm{Y}=$ Medida de Temperatura $\left({ }^{\circ} \mathrm{C}\right)$; Concentração de Peróxido (\%); $\mathrm{E}=$ Equipamento: Controle $=0,0$ e Protótipo $=1,0$.

A concentração de $\mathrm{H}_{2} \mathrm{O}_{2}$ foi significativa na análise, no entanto os equipamentos não foram capazes de diferenciar todas as concentrações entre si. A Tabela 13 elucida essa característica por meio da análise de Tukey.

Tabela 13. Médias da temperatura em relação à concentração de peróxido de hidrogênio intencionalmente adicionado ao leite azedo.

\begin{tabular}{ccc}
\hline Concentração (\%) & Temperatura Média (ㅇ) & \\
\hline $\mathbf{0 , 0 0}$ & 22,6018 & $\mathrm{C}$ \\
$\mathbf{0 , 0 5}$ & 23,8306 & $\mathrm{~B}$ \\
$\mathbf{0 , 1 0}$ & 24,0594 & $\mathrm{~B}$ \\
$\mathbf{0 , 2 5}$ & 24,0067 & $\mathrm{~B}$ \\
$\mathbf{0 , 5 0}$ & 24,4409 & $\mathrm{~A}$ \\
\hline
\end{tabular}

*Médias seguidas por letras maiúsculas iguais não diferem significativamente entre si.

Para o leite integro, apenas o teste foi significativo para o modelo de regressão, como o intuito do trabalho é o teste ser capaz de identificar a presença ou ausência de peróxido no leite, a concentração não ter sido significativa implica que o modelo também não seja para este estudo.

\subsubsection{3. $\mathrm{pH}$}

Para $\mathrm{pH}$, quando foi feito o modelo de regressão, observou-se que o teste e a condição foram significativos, no entanto como a concentração não foi significativa e, o objetivo do estudo era identificar a adição de peróxido ao leite, não foi considerado como significativo o modelo. O mesmo ocorreu para o leite integro e azedo separadamente.

Acredita-se que se forem aumentadas as concentrações de peróxido e otimizando-se o protótipo, mesmo que seja necessário substituir o sensor por outro de maior sensibilidade, as respostas sejam mais precisas e permitam a elaboração de um modelo adequado. 


\subsubsection{Formaldeído}

\subsubsection{Condutividade}

Para a Condutividade do leite adulterado com formol o modelo de regressão, tanto o equipamento como a Condição foram significativos, mas a Concentração não, o que implica dizer que para o modelo proposto não foi possível identificar a adulteração do leite, de forma geral, com formaldeído. 0 mesmo ocorreu para o leite azedo, de maneira isolada e, em ambos os casos, entende-se que o método não foi eficiente na identificação da fraude.

Para o leite integro, foram significativos na regressão o equipamento e a concentração, apresentada na eq. 8. O coeficiente de determinação do modelo foi o mais alto dos apresentados até aqui, $R^{2}=0,9534$, o que indica que o modelo representa com maior fidelidade os resultados obtidos no experimento, o Gráfico 6 representa as médias das medidas obtidas para a condutividade do leite integro e azedo adicionados de formol, em função da concentração do último. Os comportamentos observados seguem, em geral, os anteriores, mas o leite azedo apresentou uma oscilação dos seus resultados e não teve uma resposta muito conclusiva.

$Y=4,68245+0,51430 x E+0,12371 x$ Concentração $\quad R^{2}=0,9534$

Onde: $\mathrm{Y}=$ Medida de Condutividade $(\mathrm{mS} / \mathrm{cm}) ; \mathrm{E}=$ Equipamento: Controle $=0,0 \mathrm{e}$ Protótipo = 1,0; Concentração $(\%)$. 
Gráfico 6. Resposta da condutividade do leite adulterado ou não com formol diante da condição (Azedo e Integro).

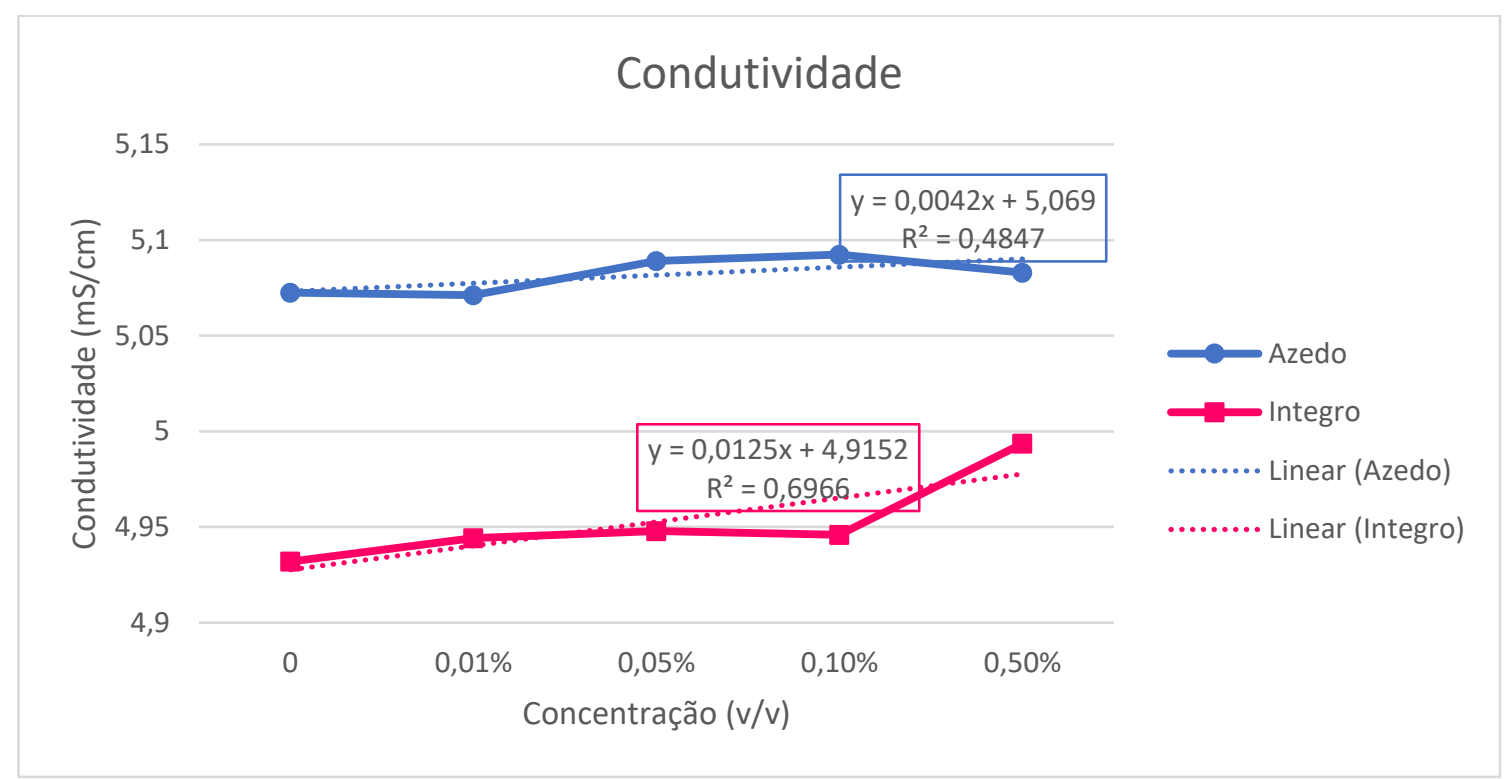

A partir da avaliação das médias da condutividade frente à concentração de formol é possível notar que apesar de serem significantes estatisticamente as diferenças delas, nem todas podem ser diferenciadas pelo modelo, quais sejam 0,01\% e $0,05 \%$, bem como $0,10 \%$ e $0,50 \%(\mathrm{v} / \mathrm{v})$. Esta análise consta na Tabela 14, na qual letras maiúsculas iguais identificam médias que não são diferentes estatisticamente entre si.

Tabela 14. Médias da condutividade em relação à concentração de formaldeído intencionalmente adicionado ao leite integro.

\begin{tabular}{ccc}
\hline Concentração (\%) & Condutividade Média (mS/cm) & \\
\hline $\mathbf{0 , 0 0}$ & 4,8995 & $\mathrm{C}$ \\
$\mathbf{0 , 0 1}$ & 4,9442 & $\mathrm{~B}$ \\
$\mathbf{0 , 0 5}$ & 4,9478 & $\mathrm{~B}$ \\
$\mathbf{0 , 1 0}$ & 4,9979 & $\mathrm{~A}$ \\
$\mathbf{0 , 5 0}$ & 4,9936 & $\mathrm{~A}$ \\
\hline
\end{tabular}

${ }^{*}$ Médias seguidas por letras maiúsculas iguais não diferem significativamente entre si.

Mesmo com essa semelhança estatística entre alguns resultados, o método para o leite integro foi capaz de diferenciar o leite adulterado do não adulterado, o que torna o modelo interessante para estudos mais aprofundados e detalhados. 


\subsubsection{Temperatura}

Analisando-se o modelo de regressão proposto para a temperatura, descrito na eq. 9, foram significativos o equipamento, a condição e a concentração. A utilização do protótipo acarreta uma redução próxima a $1^{\circ} \mathrm{C}$ em relação ao equipamento controle, entretanto a concentração ainda é o fator de maior influência sobre a variação de temperatura do modelo. O coeficiente de determinação $\left(\mathrm{R}^{2}\right)$ foi relativamente baixo, mas pode ser melhorado ajustandose o equipamento e o software, aumentando o número de repetições e reduzindo os erros experimentais.

$$
\begin{aligned}
Y=20,03714 & -0,95717 x E-0,67137 x \text { Condição } \\
& +1,32996 x \text { Concentração } \quad \mathrm{R}^{2}=0,4492
\end{aligned}
$$

Onde: $\mathrm{Y}=$ Medida de Temperatura $\left({ }^{\circ} \mathrm{C}\right)$; Condição: Azedo $=1,0$ e Integro $=0,0 ; \mathrm{E}=$ Equipamento: Controle $=0,0$ e Protótipo $=1,0$; Concentração $(\%)$.

A partir das médias dos dados obtidos no experimento foi elaborado 0 Gráfico 7, onde são apresentadas as médias de temperatura para os equipamentos controle e protótipo. As curvas apresentam-se oscilações, o que reduz seu $\mathrm{R}^{2}$, no entanto os comportamentos das curvas são semelhantes e proporcionais. Como a concentração foi significativa no modelo, fez-se a análise de Tukey, entretanto o modelo não conseguiu diferenciar todas as médias, o que pode ser observado na Tabela 15, onde médias seguidas por letras maiúsculas iguais não apresentam diferença significativa entre si. 
Gráfico 7. Médias de temperatura relacionando a concentração de formol e o equipamento.

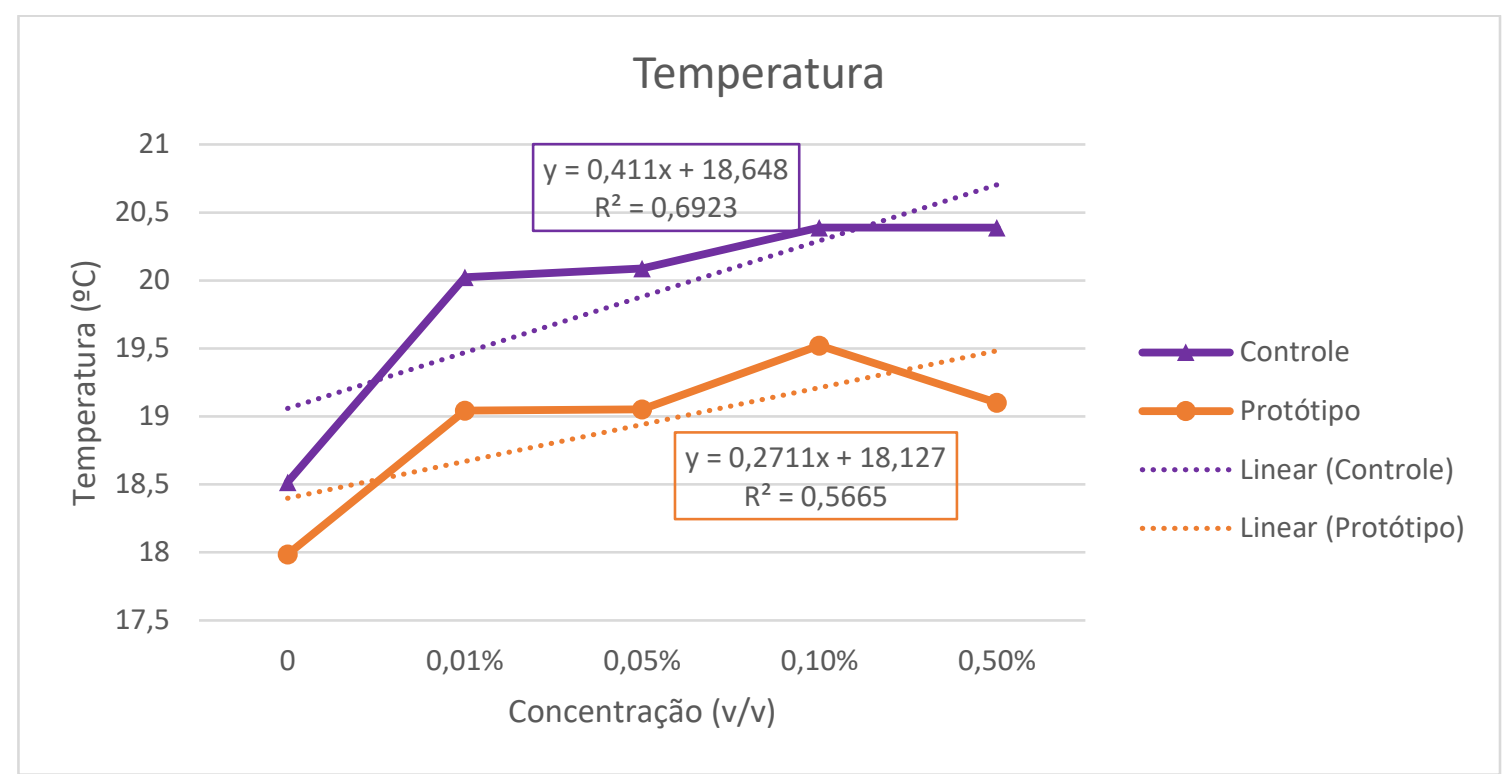

Tabela 15. Médias da Temperatura em relação à Concentração de formaldeído intencionalmente adicionado ao leite.

\begin{tabular}{ccc}
\hline Concentração (\%) & Temperatura Média ( $\left.{ }^{\circ} \mathbf{C}\right)$ & \\
\hline $\mathbf{0 , 0 0}$ & 18,2514 & $\mathrm{D}$ \\
$\mathbf{0 , 0 1}$ & 19,5035 & $\mathrm{C}$ \\
$\mathbf{0 , 0 5}$ & 19,57 & $\mathrm{BC}$ \\
$\mathbf{0 , 1 0}$ & 19,9553 & $\mathrm{~A}$ \\
$\mathbf{0 , 5 0}$ & 19,7306 & $\mathrm{~B}$
\end{tabular}

*Médias seguidas por letras maiúsculas iguais não diferem significativamente entre si.

Em relação ao modelo para o leite azedo, tanto o equipamento quanto a concentração foram significativos na análise, desta forma a eq. 10 apresenta 0 modelo proposto. A utilização do protótipo, como no modelo anterior, reduz em pouco mais de $1^{\circ} \mathrm{C}$ a temperatura de resposta.

$Y=20,15988-1,18067 x E+1,24669 x$ Concentração $\quad R^{2}=0,4141$

Onde: $\mathrm{Y}=$ Medida de Temperatura $\left({ }^{\circ} \mathrm{C}\right) ; \mathrm{E}=$ Equipamento: Controle $=0,0$ e Protótipo $=$ 1,0; Concentração (\%).

Gráfico 8. Médias de temperatura do leite azedo e integro adicionados ou não de formol. 


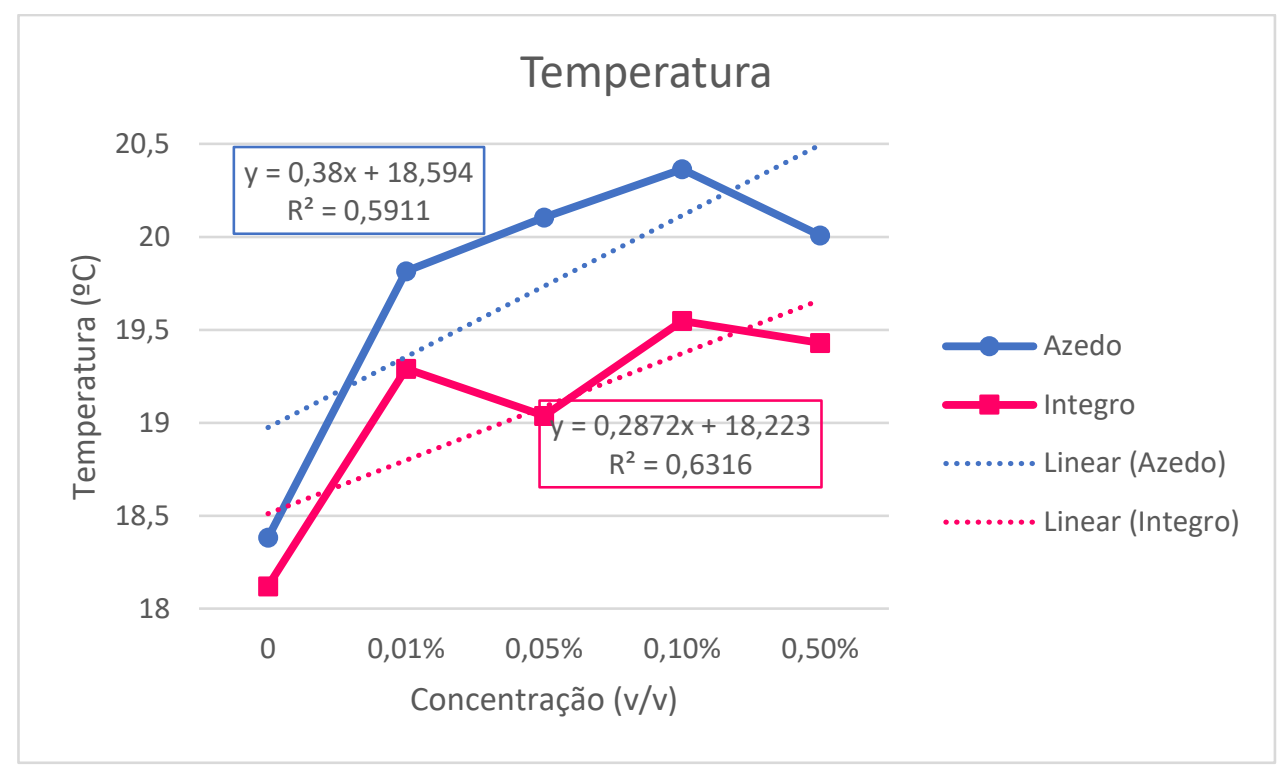

A diferenciação estatística foi vislumbrada entre quase todas as concentrações de formol adicionadas ao leite, o que pode ser visualizado na Tabela 16. As médias acompanhadas de letras maiúsculas iguais indicam que não há diferença significativa entre elas, dessa forma pode-se inferir que a temperatura é um fator que pode nos permitir diferenciar um leite adulterado com formol de um leite puro.

Tabela 16. Médias da temperatura em relação à concentração de formaldeído intencionalmente adicionado ao leite azedo.

\begin{tabular}{ccc}
\hline Concentração (\%) & Temperatura Média ( $\left.{ }^{\circ} \mathbf{C}\right)$ & \\
\hline $\mathbf{0 , 0 0}$ & 18,3817 & $\mathrm{D}$ \\
$\mathbf{0 , 0 1}$ & 19,8144 & $\mathrm{C}$ \\
$\mathbf{0 , 0 5}$ & 20,1039 & $\mathrm{~B}$ \\
$\mathbf{0 , 1 0}$ & 20,3633 & $\mathrm{~A}$ \\
$\mathbf{0 , 5 0}$ & 20,0072 & $\mathrm{BC}$ \\
\hline
\end{tabular}

*Médias seguidas por letras maiúsculas iguais não diferem significativamente entre si.

Já se tratando de efeitos fixos para o leite integro, o equipamento e a concentração foram significativos, mas para a regressão apenas o teste, assim a Tabela 17 apresenta as médias de temperatura para o leite integro em função da concentração de formaldeído intencionalmente adicionado ao leite, onde pode-se observar que o método foi capaz de diferenciar o controle das demais 
concentrações, bem como diferenciar a maior parte das concentrações umas das outras.

Tabela 17. Médias da Temperatura em relação à Concentração de formaldeído intencionalmente adicionado ao leite integro.

\begin{tabular}{ccc}
\hline Concentração (\%) & Temperatura Média (ㅇ) & \\
\hline $\mathbf{0 , 0 0}$ & 18,1211 & $\mathrm{D}$ \\
$\mathbf{0 , 0 1}$ & 19,2215 & $\mathrm{BC}$ \\
$\mathbf{0 , 0 5}$ & 19,0361 & $\mathrm{C}$ \\
$\mathbf{0 , 1 0}$ & 19,5472 & $\mathrm{~A}$ \\
$\mathbf{0 , 5 0}$ & 19,4500 & $\mathrm{AB}$ \\
\hline
\end{tabular}

*Médias seguidas por letras maiúsculas iguais não diferem significativamente entre si.

\subsubsection{3. $\mathrm{pH}$}

$\mathrm{O} \mathrm{pH}$, em termos de efeitos fixos, teve como significativos o equipamento e a condição do leite e, por sua vez, a concentração de formaldeído não foi significante na análise estatística, o que nos leva a crer que o método não foi capaz de diferenciar a amostra adulterada da não adulterada ou diferenciar as diversas concentrações em estudo. O mesmo ocorrera para os leites integro e azedo.

\subsubsection{Ureia}

\subsubsection{Condutividade}

$\mathrm{Na}$ análise do leite de forma global o equipamento não foi significativo, o que era desejado desde o princípio, visto que o intuito do trabalho era demonstrar a semelhança entre eles e sua capacidade de diferenciar o leite puro do leite adulterado, mas para o modelo de regressão o tratamento não foi significativo também, o que não nos permite afirmar a significância do modelo.

Para o leite azedo o equipamento foi significativo estatisticamente e 0 tratamento também, tanto em efeitos fixos quanto na regressão, assim o modelo de regressão está apresentado na eq. 11. Foram plotados os Gráficos 9 e 10, utilizando-se os dados obtidos nas análises, o primeiro demonstra como é a 
resposta da condutividade frente à concentração de água e ureia adicionadas ao leite utilizando-se o equipamento controle e, o segundo, se refere à resposta quando utilizado o protótipo.

$Y=6,08799-0,55272 x E-0,01039 x$ Tratamento $\quad R^{2}=0,2053$

Onde: $\mathrm{Y}=$ Medida de Condutividade $(\mathrm{mS} / \mathrm{cm}) ; \mathrm{E}=$ Equipamento: Controle $=0,0 \mathrm{e}$ Protótipo $=1,0 ;$ Tratamento $=$ Coluna Tratamento da Tabela 18, de acordo com a combinação da concentração de água frente a concentração de ureia.

Tabela 18. Definição do valor de cada Tratamento frente as concentrações de água e ureia adicionadas ao leite.

\begin{tabular}{cccccc}
\hline Tratamento & $\begin{array}{c}\text { Concentração } \\
\text { de Água }\end{array}$ & $\begin{array}{c}\text { Concentração } \\
\text { de Ureia }\end{array}$ & Tratamento & $\begin{array}{c}\text { Concentração } \\
\text { de Água }\end{array}$ & $\begin{array}{c}\text { Concentração } \\
\text { de Ureia }\end{array}$ \\
\hline 11 & $0 \%$ & $0,00 \%$ & 13 & $10 \%$ & $0,00 \%$ \\
21 & $0 \%$ & $0,05 \%$ & 23 & $10 \%$ & $0,05 \%$ \\
31 & $0 \%$ & $0,15 \%$ & 33 & $10 \%$ & $0,15 \%$ \\
41 & $0 \%$ & $0,25 \%$ & 43 & $10 \%$ & $0,25 \%$ \\
51 & $0 \%$ & $0,50 \%$ & 53 & $10 \%$ & $0,50 \%$ \\
12 & $5 \%$ & $0,00 \%$ & 14 & $15 \%$ & $0,00 \%$ \\
22 & $5 \%$ & $0,05 \%$ & 24 & $15 \%$ & $0,05 \%$ \\
32 & $5 \%$ & $0,15 \%$ & 34 & $15 \%$ & $0,15 \%$ \\
42 & $5 \%$ & $0,25 \%$ & 44 & $15 \%$ & $0,25 \%$ \\
52 & $5 \%$ & $0,50 \%$ & 54 & $15 \%$ & $0,50 \%$ \\
\hline
\end{tabular}

Gráfico 9. Médias da condutividade medida pelo equipamento controle utilizando-se diferentes concentrações de água e ureia adicionadas ao leite azedo e integro. 


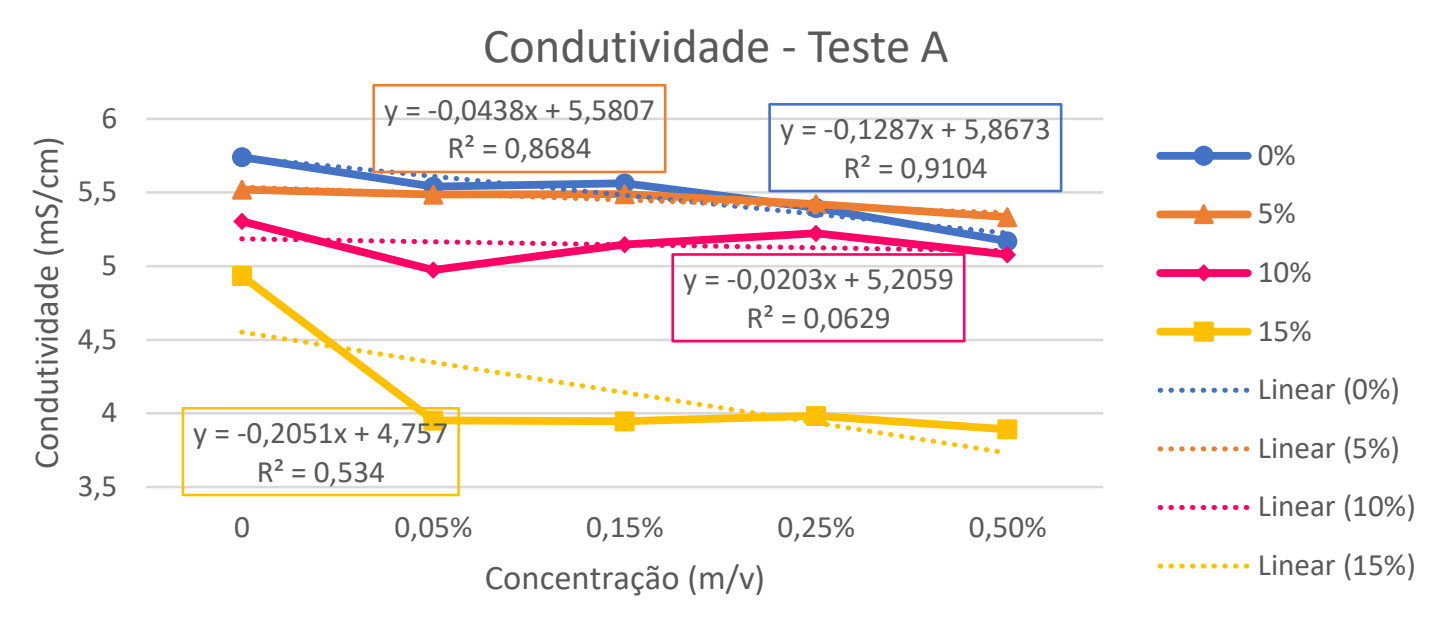

Gráfico 10. Médias da condutividade medida pelo equipamento protótipo utilizando-se diferentes concentrações de água e ureia adicionadas ao leite azedo e integro.

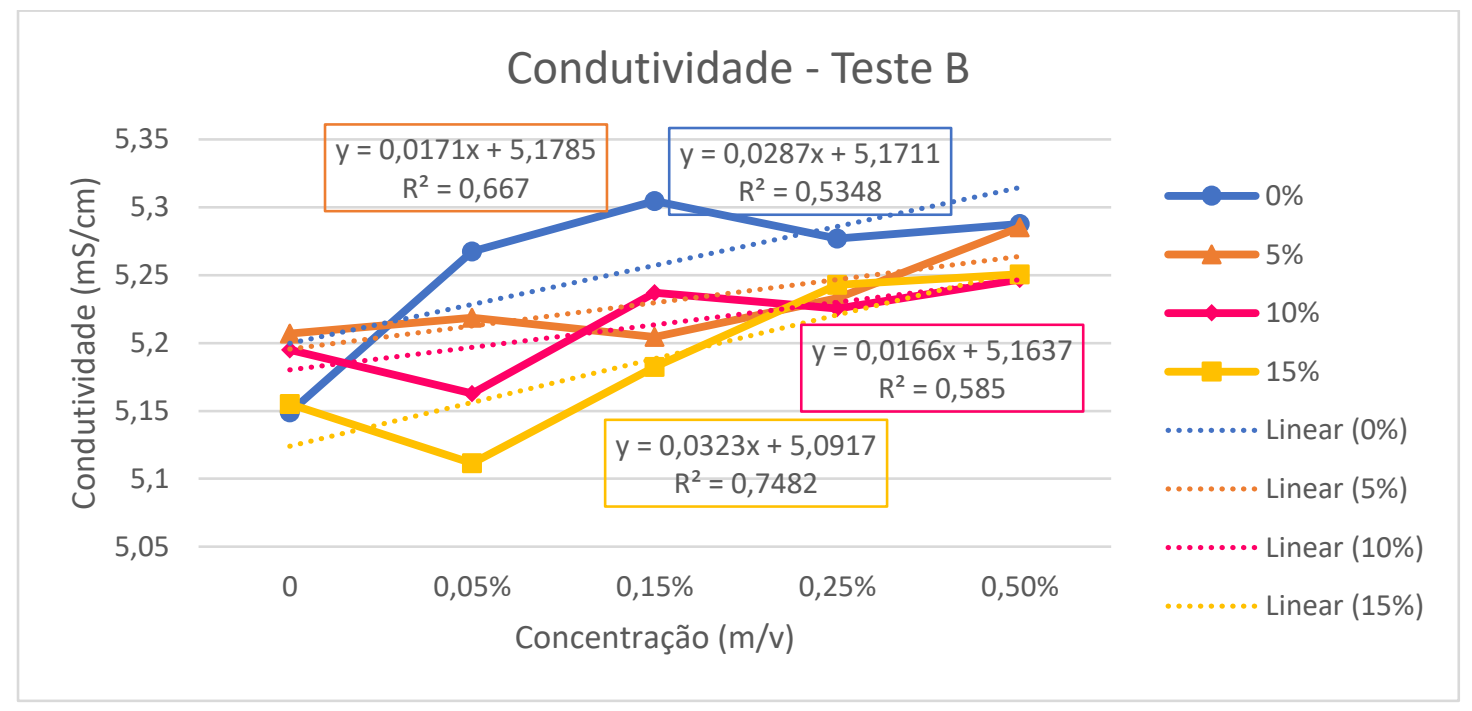

Pode-se notar que, em ambos os gráficos a variação de valores não é muito grande e que a condutividade é reduzida à medida que aumentam as concentrações de ureia e água. As concentrações influenciam de forma bastante discreta a resposta dos equipamentos, com decréscimo em torno de $0,01^{\circ} \mathrm{C}$, proporcionalmente a elas, aqui combinadas na variável denominada Tratamento. Já em relação ao leite integro, o tratamento não foi significativo na análise, o modelo de regressão também não.

\subsubsection{Temperatura}


Para a temperatura do leite de forma global adicionado com ureia e água, em relação aos efeitos fixos, o tratamento (combinação de cada concentração ureia vs. água) não foi significativo, mas o equipamento e a condição sim. No entanto, como a análise não permitiu diferenciar as concentrações de ureia e água adicionadas ao leite, então o modelo de regressão proposto não foi significativo.

Para o leite azedo e para o leite integro, o mesmo resultado do leite de forma global foi observado, assim o tratamento não foi significativo para a análise de regressão da temperatura, o que demonstra a inadequação do parâmetro Temperatura para diferenciar os tratamentos.

\subsubsection{3. $\mathrm{pH}$}

Para o leite de forma global no modelo de regressão além de não ser significativo o equipamento, o tratamento também não foi significativo, assim não se pode afirmar a significância do modelo. Para o leite azedo, o mesmo ocorreu, não sendo significativo o modelo de regressão para ele e, em relação ao leite integro, observou-se que apenas o equipamento foi significativo, o que inviabiliza a utilização do modelo de regressão.

De forma geral, para a ureia combinada com a água a analise realizada não foi significativa, o que mostra a necessidade de estudos mais aprofundados, alteração das concentrações analisadas e, até mesmo, revisão dos modelos de sensores e estatísticos utilizados para análise das amostras. O resultado também indica a eficiência do método de adulteração comumente utilizado para mascarar os leites inadequados ao consumo.

\section{Conclusão}

Com base nas análises realizadas pode-se concluir que o equipamento apresentou potencial para identificar a adição de hidróxido de sódio e formaldeído ao leite, entretanto, para o peróxido de hidrogênio e para a combinação ureia vs. água ele não se mostrou eficiente e nem capaz de diferenciar o leite adulterado do não adulterado nas concentrações e condições 
estudadas. O resumo da eficiência das análises pode ser observado no Quadro 2, relacionando os diversos parâmetros analisados.

Os resultados do pHmetro não se mostraram conclusivos, o que implica na necessidade de novos estudos, que vislumbrem desde a alteração das concentrações estudadas, um maior número de repetições e a montagem do circuito integrado com o intuito de reduzir os erros experimentais.

Os estudos de condutividade e temperatura foram mais promissores, mas a realização das mesmas adaptações propostas ao pHmetro podem ajudar a melhorar a resposta, o coeficiente de correlação e a representatividade do modelo.

Quadro 2. Eficiência de cada variável para identificar em cada tipo de leite a adição dos adulterantes estudados.

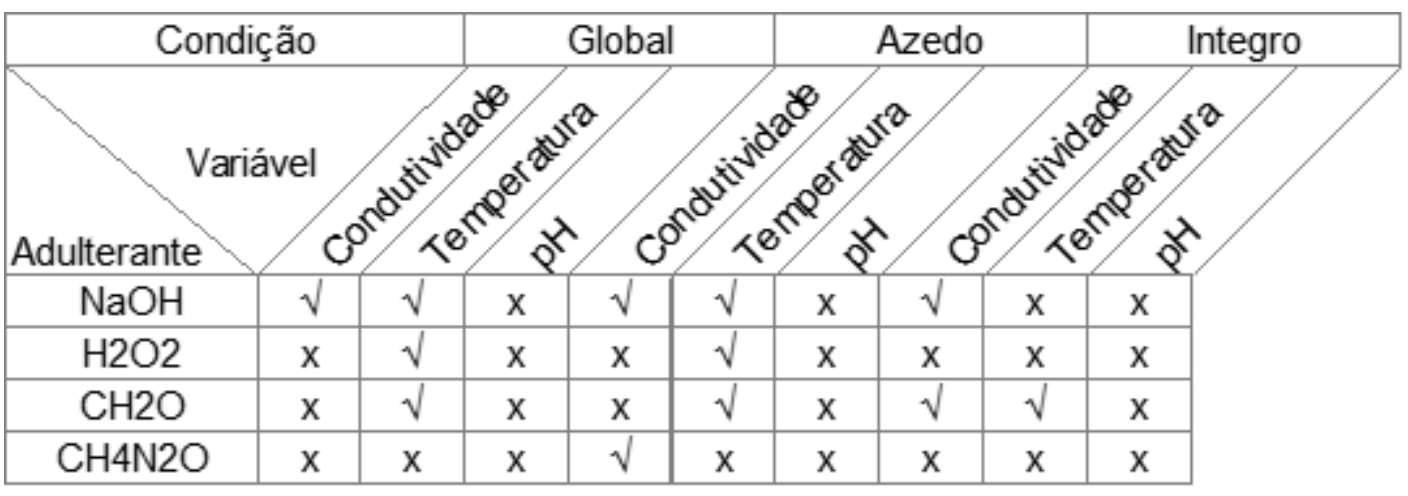

\section{Sugestões para Trabalhos Futuros}

Em trabalhos futuros sugere-se otimizar o equipamento desenvolvido utilizando sensores de precisão mais alta, bem como propõe-se reduzir erros experimentais com a transformação do protótipo em circuito integrado, fazendo o delineamento e a impressão do circuito elétrico em placas, eliminando o uso da protoboard. Ainda mais adiante, pode-se expandir a gama de aditivos identificado ou trabalhar a identificação de contaminação bacteriológica e microbiana no leite. 


\section{Referências}

ABRANTES, Maria Rociane, CAMPÊLO, Carla da Silva e SILVA, Jean Berg Alves da. 2014. Fraude em Leite: Métodos de Detecção e Implicações para o Consumidor. Revista Instituto Adolfo Lutz. 73, 2014, Vol. 3. DOI: 10.18241/0073-98552014731611.

ALVES, Leonardo Sehn. 2016. Desenvolvimento de Medidor de Condutividade Elétrica da Água para fins de Monitoramento Ambiental. Trabalho de diplomação em Engenharia Física apresentado à Universidade Federal do Rio Grande do Sul (UFRGS) como exigência para obtenção do grau de Bacharelado em Engenharia Física. 2016.2 Disponível em: <https://lume.ufrgs.br/bitstream/handle/10183/150061/001005224.pdf?sequenc $\mathrm{e}=1$ \&isAllowed $=\mathrm{y}>$ Acesso em: dez/2019.

ANDRADE, João Carlos de. 2010. Química Analítica Básica: Os conceitos acidobase e a escala de pH. Chemkeys. Licenciado sob Creative Commons (BY-NC$\mathrm{SA})$.

Disponível em: https://econtents.bc.unicamp.br/inpec/index.php/chemkeys/article/download/964 2/5061/> Acesso em dez/2019.

ANDRADE, Carlos Alberto Araújo de; et al. 2016. Avaliação de um módulo de reconhecimento de fala na plataforma Arduino. Revista Principia. 2016. Divulgação Científica e Tecnológica do IFPB № 29. Disponível em: <http://periodicos.ifpb.edu.br/index.php/principia/article/view/71> Acesso em: 13/03/2019.

ANVISA - Agência Nacional De Vigilância Sanitária. 2007a. Uma análise dos achados laboratoriais sobre ocorrências de fraudes em Leite UHT (UAT) Polícia Federal, Operação "Ouro Branco". Informe Técnico no 34. Disponível em: $\quad<\quad$ http://portal.anvisa.gov.br/resultado-debusca?p_p_id $=101 \& p \_p \_l i f e c y c l e=0 \& p \_p \_s t a t e=$ maximized\&p_p_mode $=v i e w \&$ p_p_col_id=column-

1\&p_p_col_count=1\&_101_struts_action=\%2Fasset_publisher\%2Fview_conten t\&_101_assetEntryld=2775173\&_101_type=content\&_101_groupld=33916\&_1 01_urlTitle=informe-tecnico-n-34-de-31-de-outubro-de2007\&inheritRedirect=true> Acesso em: 15 de julho de 2018.

ANVISA - Agência Nacional De Vigilância Sanitária. 2013. Esclarecimentos sobre os riscos à saúde das substâncias ureia e formol e sua adição ao leite. Informe Técnico no $53 . \quad$ Disponível em: <http://portal.anvisa.gov.br/documents/33916/388729/Informe+T\%C3\%A9cnico $+n \% C 2 \% B A+53 / 49915 d 61-509 a-4782-a 45 c-2 f 1 a 5 e 7117 f 0>$ Acesso em: 15 de julho de 2018.

ANVISA - Agência Nacional De Vigilância Sanitária. 2018. Aditivos Alimentares 
E Coadjuvantes De Tecnologia - Aditivos Alimentares Organizada Por Categoria De Alimentos. Consolidado da Legislação Brasileira Organizada Por Categoria de Alimento. Disponível em: < http://portal.anvisa.gov.br/aditivosalimentares-organizada-por-categoria-de-alimentos> Acesso em: 31 de julho de 2018.

ANVISA - Agência Nacional De Vigilância Sanitária. 2007b. Hidróxido de Sódio (hidróxido de sódio) - INS 524. Informe Técnico no33. Disponível em: $<$ http://portal.anvisa.gov.br/informacoes-

tecnicas13?p_p_id=101_INSTANCE_WvKKx2fhdjM2\&p_p_col_id=column-

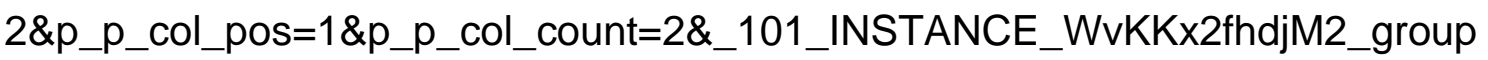
Id=33916\&_101_INSTANCE_WvKKx2fhdjM2_urITitle=informe-tecnico-n-33-de25-de-outubro-de-

2007\&_101_INSTANCE_WvKKx2fhdjM2_struts_action=\%2Fasset_publisher\% 2Fview_content\&_101_INSTANCE_WvKKx2fhdjM2_assetEntryld=2775154\&_1 01_INSTANCE_WvKKx2fhdjM2_type=content> Disponível em: 31 de julho de 2018.

ANVISA - Agencia Nacional de Vigilância Sanitária. 2016. Codex Alimentarius. Disponível em:

http://portal.anvisa.gov.br/documents/33916/388701/Codex+Alimentarius/10d27 6cf-99d0-47c1-80a5-14de564aa6d3> Acesso em: dez/2019.

APCBRH - Associação Paranaense de Criadores de Bovinos da Raça Holandesa/ APCGH - Associação Paulista dos Criadores de Gado Holandês. Programa de Análise de Rebanhos Leiteiros do Paraná - Sumário do Rebanho. 2019. Relatórios de Junho e Julho de 2019 disponibilizados pela Seção de Bovinos de Leite da DVAGRO (Divisão de Produção Agropecuária) do Campus da Faculdade de Zootecnia e Engenharia de Alimentos (FZEA/USP).

ARDUINO. 2018. What is Arduino? Disponível em: <https://www.arduino.cc/en/Guide/Introduction>. Acesso em: Agosto de 2018.

ARDUINO. 2019a. Arduino Nano. Disponível em: <https://store.arduino.cc/arduino-nano> Acesso em: Agosto de 2019.

ARDUINO. 2019b. Arduino Uno Rev3. Disponível em: <https://store.arduino.cc/arduino-uno-rev3> Acesso em: Agosto de 2019.

ARDUINO. 2019c. LilyPad Arduino Main Board. Disponível em: $<$ https://www.arduino.cc/en/Main/ArduinoBoardLilyPad/> Acesso em: Agosto de 2019.

ARDUINO. 2019d. Arduino Mega 2560. Disponível Em: <https://store.arduino.cc/mega-2560-r3>. Acesso em: Agosto de 2019.

AVALLONE, Elson et al. 2019. An inexpensive anemometer using Arduino board. Facta Universitatis-Series Electronics And Energetics. Vol.: 32; Ed.: 3; Set. 
2019. Páginas: 359-368. DOI: 10.2298/FUEE1903359A. Disponível em: < http://casopisi.junis.ni.ac.rs/index.php/FUElectEnerg/article/view/4908/3057> Acesso em: julho de 2019.

BAGGIO, Ana Paula; MONTANHINI, Maike Thaís Maziero. 2017. Qualidade de leite cru produzido na região do Norte Pioneiro do Paraná. Revista Brasileira de Higiene e Sanidade Animal (v.11, n.2) p. 184 -189, abr - jun (2017).

BARR, Michael. "Embedded Systems Glossary." Disponível em: <https://barrgroup.com/Embedded-Systems/Glossary> Acesso em: julho de 2019.

BARROS, Lucas. 2018. Tipos de Arduino. Disponível em: < https://medium.com/tht-things-hackers-team/tipos-de-arduino-3c3206c46bc> Acesso em: Agosto de 2019.

BIGGS, D. A. 1967. Milk Analysis with the Infrared Milk Analyzer. Journal of Dairy Science. Volume 50, Issue 5, May 1967, Pages 799-803. Disponível em: <https://doi.org/10.3168/jds.S0022-0302(67)87519-2> Acesso em: maio de 2017.

BRASIL. 2017. RIISPOA - Regulamento de Inspeção da Indústria de Produtos de Origem Animal. Decreto № 9.013, De 29 De Março De 2017. Regulamenta a Lei $n^{\circ}$ 1.283, de 18 de dezembro de 1950, e a Lei $n^{\circ}$ 7.889, de 23 de novembro de 1989, que dispõem sobre a inspeção industrial e sanitária de produtos de origem animal. Presidência da República - Casa Civil: Subchefia para Assuntos Jurídicos, $2017 . \quad$ Disponível em: <http://www.planalto.gov.br/ccivil_03/_Ato2015-2018/2017/Decreto/D9013.htm> BRASIL. 2018. INSTRUÇÃO NORMATIVA № 76, DE 26 DE NOVEMBRO DE 2018. Ministério da Agricultura, Pecuária e Abastecimento, 2018. Disponível em: $\quad<\quad$ http://www.in.gov.br/materia//asset_publisher/Kujrw0TZC2Mb/content/id/52750137/do1-2018-11-30instrucao-normativa-n-76-de-26-de-novembro-de-2018-52749894IN\%2076> Acesso em: julho de 2019.

BURATTI, Susanna; BENEDETTI, Simona; GIOVANELLI, Gabriella. 2017. Application of electronic senses to characterize espresso coffees brewed with different thermal profles. Eur. Food. Res. Technol. 2017, 243 p.:511-520. DOI 10.1007/s00217-016-2769-y.

CATI - Secretaria de Agricultura e Abastecimento de São Paulo: Coordenadoria de Desenvolvimento Rural Sustentável. 2019. Mastite Bovina. Disponível em: < http://www.cati.sp.gov.br/portal/produtos-e-servicos/publicacoes/acervotecnico/mastite-bovina> Acesso em: agosto de 2019.

CODEX STAN 206-1999. General Standard for the use of dairy terms. Disponível em: <http://www.fao.org/fao-who-codexalimentarius/sh- 
proxy/en/?Ink=1\&url=https\%253A\%252F\%252Fworkspace.fao.org\%252Fsites $\% 252 F$ codex\%252FStandards\%252FCODEX\%2BSTAN\%2B2061999\%252FCXS_206e.pdf> Acesso em: 10/02/2019.

CORREIO DO POVO. 2018. Justiça condena 16 pessoas por fraudes em leite distribuído no RS. Disponível em: < https://www.correiodopovo.com.br/not\%C3\%ADcias/geral/justi\%C3\%A7acondena-16-pessoas-por-fraudes-em-leite-distribu\%C3\%ADdo-no-rs1.268323> Acesso em: julho de 2019.

COSTA, Maurília P. da. Desenvolvimento de biossensor impedimétrico para detecção de Mycobacterium tuberculosis baseado em ácido mercaptobenzóico (AMB) e nanoparticulas magnéticas. Dissertação de Mestrado apresentada ao Programa de Pós-Graduação em Bioquímica e Fisiologia da Universidade Federal de Pernambuco - Centro De Ciências Biológicas. Recife, 2014. Disponível em: <http://repositorio.ufpe.br/bitstream/handle/123456789/12109/DISSERTA\%C3 \%87\%C3\%830\%20Maur\%C3\%ADlia\%20Palmeira\%20da\%20Costa.pdf?seque nce=1\&isAllowed=y $>$ Acesso em: maio de 2017.

CRUZ, Adriano G. et al., 2016. Química, bioquímica, análise sensorial e nutrição no processamento de leite e derivados. Coleção Lácteos. Vol.1. 1a. Ed. Rio de Janeiro: Elsevier. 282 p.

CRUZ, Adriano G. et al., 2017. Processamento de leites de consumo. Coleção Lácteos. Vol. 2. 1a․ Ed. Rio de Janeiro: Elsevier. 355 p.

CRUZ, Adriano G. et al., 2019. Microbiologia, higiene e controle de qualidade no processamento de leites e derivados. Coleção Lácteos. Vol. 4. 1a. Ed. Rio de Janeiro: Elsevier. 355 p.

DE LIMA, Maria Auxiliadora Coêlho. Segurança de Alimentos. Disponível em: <http://www.agencia.cnptia.embrapa.br/Agencia22/AG01/arvore/AG01_179_24 112005115229.html> Acesso em: agosto de 2018.

DI ROSA, A.R., et al. Fusion of electronic nose, electronic tongue and computer vision for animal source food authentication and quality assessment - A review, Journal of Food Engineering. 2017. Disponível em: <http://dx.doi.org/10.1016/j.jfoodeng.2017.04.024> Acesso em: maio de 2017.

DOS SANTOS, Marcos Felipe Sobral; MORENO, Edward David. Mapeamento Tecnológico e Científico das Aplicações de Ações de Controle em Sistemas Embarcados. 2 CONGENTI - Congresso de Gestão, Negócios e Tecnologia da Informação. Disponível em: < https://eventos.set.edu.br/index.php/congenti/article/view/9659> Acesso em: julho de 2019. 
ESTADÃO INTERNACIONAL. 2009. China condena dois à morte por leite adulterado. Estadão Internacional - Agencias Internacionais. Disponível em: $<$ http://internacional.estadao.com.br/noticias/geral,china-condena-dois-a-mortepor-leite-adulterado,311152> Acesso em: maio de 2017.

FACURE, Murilo H.M. et al. 2017. Detection of trace levels of organophosphate pesticides using an electronic tongue based on graphene hybrid nanocomposites. Talanta. 2017, 167 p.: 59-66. Disponível em: <http://dx.doi.org/10.1016/j.talanta.2017.02.005>

FAGNANI, Rafael. 2016. Principais Fraudes em Leite. Disponível em: < https://www.milkpoint.com.br/colunas/rafael-fagnani/principais-fraudes-em-leite100551n.aspx> Acesso em: julho de 2019.

FAO e IDF. 2013. Guia de boas práticas na pecuária de leite. Produção e Saúde Animal Diretrizes. 8. Roma.

FDA - Food and Drugs Administration. 2018. What does FDA regulate?. Disponível em: <https://www.fda.gov/about-fda/fda-basics/what-does-fdaregulate $>$ Acesso em: dez/2019.

FDA - Food and Drugs Administration. 2016. Code of Federal Regulations. Title 21, Volume 2. Revised as of April 1, 2016. Disponível em: < https://www.ecfr.gov/cgi-bin/text-

idx?SID=224044ad091c1f51173a77ab85ff5e50\&mc=true\&node=pt21.2.131\&rg $\mathrm{n}=$ div5\#sp21.2.131.a $>$ Acesso em: maio de 2017.

G1. 2008. Leite adulterado mata pelo menos cinco crianças na Índia, diz hospital. G1.com. Disponível em: <http://g1.globo.com/Noticias/Mundo/0,,MUL862153$5602,00-$

LEITE+ADULTERADO+MATA+PELO+MENOS+CINCO+CRIANCAS+NA+INDI A+DIZ+HOSPITAL.html> Acesso em: maio de 2017.

G1. 2014. Mais duas marcas de leite têm venda proibida no RJ: Parmalat e Líder - Procon já havia proibido a comercialização de Elegê. G1.com. Disponível em: <http://g1.globo.com/rio-de-janeiro/noticia/2014/03/mais-duas-marcas-de-leitetem-venda-proibida-no-rj-parmalat-e-lider.html> Acesso em: maio de 2017.

G-100 - Associação Brasileira das Pequenas e Médias Cooperativas e Empresas de Laticínios. 2018. Lácteos Seguros. Disponível em < https://www.g100.org.br/site/index.php/conte\%C3\%BAdo/l\%C3\%A1cteosseguros> Acesso em: 15 de julho de 2018.

G1 RS. 2015. Leite adulterado no RS chegou à mesa do consumidor, diz MP. G1.COM. Disponível em: <http://g1.globo.com/rs/rio-grande-dosul/noticia/2015/09/leite-adulterado-no-rs-chegou-mesa-do-consumidor-dizmp.html> Acesso em: 12/02/2019. 
IARC - International Agency for Research on Cancer. Formaldehyde. Disponível em: $<$ https://monographs.iarc.fr/wpcontent/uploads/2018/06/mono100F-29.pdf> Acesso em: agosto de 2018.

IDF - International Dairy Federation. 2014. Risk-Based Food Safety Management. IDF Factsheet - December 2014. Disponível em: <https://www.filidf.org/wp-content/uploads/2016/08/Risk-Based-Food-Safety-Management.pdf> Acesso em: agosto de 2018.

INCA - Instituto Nacional de Câncer José Alencar Gomes da Silva. 2018. Formol ou Formaldeído. Disponível em: <http://www1.inca.gov.br/conteudo_view.asp?ID=795> Acesso em: agosto de 2018.

ISOLAB. 2001. Peróxido de Hidrogênio e Soluções Aquosas - Ficha de informações de segurança. Disponível em: < https://cloud.cnpgc.embrapa.br/wpcontent/igu/fispq/laboratorios/Per\%C3\%B3xido\%20de\%20hidrog\%C3\%AAnio.p df> Acesso em: agosto de 2018.

KOBLITZ, Maria Gabriela Bello. 2011. Matérias-primas alimentícias: Composição e Controle de Qualidade. Rio de Janeiro: Guanabara Koogan, 2011.

KUMAR, Y. V. Niranjan et al. 2013. A Novel Implementation of Phase Control Technique for Speed Control of Induction Motor Using ARDUINO. International Journal of Emerging Technology and Advanced Engineering. ISSN 22502459. Volume 3, Issue 4, Abril, 2013. Disponível em: < http://citeseerx.ist.psu.edu/viewdoc/download?doi=10.1.1.413.5840\&rep=rep1\&t ype=pdf> Acesso em: julho de 2019.

LARA, Gabriela. 2015. MP-RS cumpre mandados de prisão contra fraudes no leite. Exame.com. Editora Abril, 13 de maio de 2015. Disponível em:<http://exame.abril.com.br/brasil/mp-rs-cumpre-mandados-de-prisao-contrafraudesno-leite/> Acesso em: outubro de 2016.

LEHMEN, Fábio. 2017. Quadrilha usava hidróxido cáustica e outras substâncias para adulterar leite - De acordo com o Ministério Público, indústrias no RS usavam água e substâncias como hidróxido cáustica para reaproveitar produtos vencidos. Hora $1 . \quad$ Disponível em: <http://g1.globo.com/hora1/noticia/2017/03/quadrilha-usava-hidróxido-causticae-outras-substancias-para-adulterar-leite.html> Acesso em: maio de 2017.

MANUEL, Chandra et al. 2019. Customizable Smart Food Cabinet and Refrigerator. Pertanika Journal of Science and Technology. Vol.: 27, Ed.: 1, Jan. 2019. Páginas: 143-157. Disponível em: < http://www.pertanika.upm.edu.my/Pertanika\%20PAPERS/JST\%20Vol.\%2027\% 20(1)\%20Jan.\%202019/07\%20JST-1127-2018.pdf> Acesso em: Julho de 2019. 
MAPA - Ministério da Agricultura, Pecuária e Abastecimento. 2008. PORTARIA № 198, DE 19 DE NOVEMBRO DE 2008. Disponível em: < https://www.apcbrh.com.br/files/PORTARIA1982008_CREDENCIAMENTO.PD F> Acesso em: agosto de 2019.

MAPA - Ministério da Agricultura, Pecuária e Abastecimento. 2014. Operação Leite Adulterado I e II. Ministério da Agricultura. Agosto de 2014. Disponível em:<http://www.agricultura.gov.br/animal/noticias/2014/08/operacao-leiteadulterado-ie-ii> Acesso em: outubro de 2016.

MUNDO EDUCAÇÃO. DIAS, Diogo Lopes. Lactose. Disponível em: < https://mundoeducacao.bol.uol.com.br/quimica/lactose.htm> Acesso em: julho de 2019.

NASCIMENTO, Carina F. et al. 2017. Recent advances on determination of milk adulterants. Food Chemistry, 221. 2017. p.: 1232-1244. Disponível em: <http://dx.doi.org/10.1016/j.foodchem.2016.11.034> Acesso em: fevereiro de 2017.

NASCIMENTO, Wesley, et al. 2010. Uso de medidas de condutividade elétrica para a detecção de adição de água, cloreto de sódio e hidróxido cáustica no leite. Rev. Inst. Latic. "Cândido Tostes". Jul/Ago 2010, № 375, 65.

NATIONAL CENTER FOR BIOTECHNOLOGY INFORMATION. 2019. PubChem Database. Sodium hydroxide, $\quad C I D=14798$. Disponível em: <https://pubchem.ncbi.nlm.nih.gov/compound/Sodium-hydroxide>. Acesso em: out. de 2019.

NATIONAL CENTER FOR BIOTECHNOLOGY INFORMATION. 2019a. PubChem Database. Urea, $\quad C I D=1176$. Disponível em: <https://pubchem.ncbi.nlm.nih.gov/compound/Urea >. Acesso em: out. de 2019.

NATIONAL CENTER FOR BIOTECHNOLOGY INFORMATION. $2019 \mathrm{~b}$. PubChem Database. Hydrogen peroxide, $C I D=784$. Disponível em: <https://pubchem.ncbi.nlm.nih.gov/compound/Hydrogen-peroxide> Acesso em: out. de 2019.

NAZÁRIO, Sergio Luiz Sousa, et al. 2009. Caracterização de Leite Bovino Utilizando Ultra-som e Redes Neurais Artificiais. Revista Controle \& Automação. 2009, Vol. 20, 4.

OGA, Seizi; CAMARGO, Márcia Maria de Almeida; BATISTUZZO, José Antônio de Oliveira. 2008. Fundamentos de Toxicologia. Grupo Zanini-Oga. $3^{a}$ Ed. São Paulo: Atheneu Editora São Paulo. 677p.

OPEN SOURCE. 2018. What is a Raspberry Pi?. Disponível em: < https://opensource.com/resources/raspberry-pi> Acesso em: Set. de 2018. 
QUÍMICA MARAGNO. 2018. FISPQ - Ficha de Segurança de Produtos Químicos. Disponível em: < http://quimicamaragno.com.br/FISPQ/67.pdf> Acesso em: agosto de 2018.

ROSOLEM, Marcia. 2013. Influência da alimentação nos níveis de ureia em leite bovino. Trabalho de Conclusão de Curso apresentado à Univates para Obtenção do título de Bacharel em Química Industrial. Lajeado. Disponível em: <https://www.univates.br/bdu/bitstream/10737/400/1/MarciaRosolen.pdf>

SKOCZEK, Justyna et al. 2019. A multi-pumping flow analysis system for betagalactosidase activity assays. FOOD CHEMISTRY. Vol.: 294, Out. 2019. Páginas: 231-237. DOI: 10.1016/j.foodchem.2019.04.045. Disponível em: < https://www.sciencedirect.com/science/article/pii/S0308814619306958?via\%3Di hub> Acesso em: Julho de 2019.

SOUSA, V. F. de; MAROUELLI, W. A.; COELHO, E. F.; PINTO, J. M.; COELHO FILHO, M. A. (Ed.). (Ed.). 2011. Irrigação e fertirrigação em fruteiras e hortaliças. Brasília, DF: Embrapa Informação Tecnológica, 2011.

SOUZA, Fernando Silvio de. Sensores amperométricos nanoestruturados para determinação de $\mathrm{H}_{2} \mathrm{O}_{2}$ em amostras de uso cosmético e de higiene pessoal. Tese (Doutorado) - Centro de Ciências Físicas e Matemáticas. Florianópolis, 2015. Disponível em: < https://repositorio.ufsc.br/bitstream/handle/123456789/134666/333875.pdf?seq uence $=1$ \&isAllowed $=\mathrm{y}>$ Acesso em: maio de 2017 .

TRONCO, Vania Maria. 2013. Manual para Inspeção da Qualidade do Leite. 5ª ed. Santa Maria: Ed. Da UFSM, 2013. 208 p.

VALENTE, G.F. S. et al. 2014. Aplicação de redes neurais artificiais como teste de detecção de fraude de leite por adição de soro de queijo. Rev. Inst. Laticínios "Cândido Tostes", Juiz de Fora, v. 69, n. 6, p. 425-432, nov/dez, 2014. DOI: 10.14295/2238-6416.v69i6.353.

VENTURINI FILHO, Waldemar Gastoni et al. 2010. Bebidas não-alcoólicas: Ciência e Tecnologia, Vol. 2,São Paulo: Blucher, 2010.

VLASOV Y, LEGIN A, RUDNITSKAYA A, DI NATALE C. D'AMICO A. 2005. Nonspecifc sensor arrays ("electronic tongue") for chemical analysis of liquids (IUPAC Technical Report). Pure Appl Chem. 2005, 77(11):1965-1983. DOI: 10.1351/pac200577111965.

YANG, Shunchang et al. 2019. Low-cost, Arduino-based, portable device for measurement of methane composition in biogas. Renewable Energy. Vol. 138, Ago. 2019, Pages 224-229. https://doi.org/10.1016/j.renene.2019.01.083. Disponível em:

https://www.sciencedirect.com/science/article/pii/S0960148119300965?via\%3Di hub> Acesso em: Julho de 2019. 
ZOU, Y et al. 2015. Electronic Nose and Electronic Tongue. Chapter 2. Bioinspired Smell and Taste Sensors. Science Press, Beijing and Springer Science + Business Media Dordrecht. 2015. P. Wang et al. (eds.), DOI: 10.1007/978-94-017-7333-1_2 